\title{
MINERALOGICAL AND OXYGEN ISOTOPIC CONSTRAINTS ON THE ORIGIN OF THE CONTACT-METAMORPHOSED BEDDED MANGANESE DEPOSIT AT NAGASAWA, JAPAN
}

\author{
MAKOTO HARUNA ${ }^{\S}$ \\ Geological Museum, National Institute of Advanced Industrial Science and Technology, \\ 1-1-1 Higashi, Tsukuba, Ibaraki, 305-8567, Japan \\ HISAO SATOH ${ }^{\S}$ AND YASUYUKI BANNO ${ }^{\S}$ \\ National Institute of Advanced Industrial Science and Technology, 1-1-1 Higashi, Tsukuba, Ibaraki, 305-8567, Japan \\ MASAHIDE KONO \\ Takata Cooperation, Inada, Kasama, Ibaraki, 309-1635, Japan \\ MicHIAKI BUNNO \\ Geological Museum, National Institute of Advanced Industrial Science and Technology, \\ 1-1-1 Higashi, Tsukuba, Ibaraki, 305-8567, Japan
}

\begin{abstract}
The Nagasawa deposit, in Japan, is a Paleozoic to Mesozoic chert-hosted bedded manganese deposit that has undergone intense contact metamorphism due to intrusion of a granitic pluton $c a .59$ to $62 \mathrm{Ma}$ in age. The manganese ores occur as stratiform manganese silicates and quartz-dominant veins. A detailed petrographic and mineralogical study of ore samples reveals that $\mathrm{Fe}-, \mathrm{Co}-, \mathrm{Ni}-, \mathrm{Cu}-, \mathrm{Zn}-, \mathrm{As}-, \mathrm{Te}-, \mathrm{Pb}-$, and $\mathrm{Bi}$-minerals (including native elements, sulfides, arsenides, and tellurides) are commonly present in both types of ore, and that molybdenite occurs in the veins. These minerals are closely associated with garnet in the pyroxmangite - garnet - amphibole ore that was metamorphosed from the rhodochrosite - quartz - chlorite assemblage commonly observed in unmetamorphosed manganese carbonate ores. The calculated oxygen isotopic temperatures based on mineral pairs obtained from the same hand samples of bedded ore scatter widely and include the temperature range estimated from equilibria among metamorphic minerals. The inconsistency in temperature ranges is ascribed to oxygen isotope disequilibrium among all the analyzed minerals from the bedded ores and suggests that externally derived fluid phases were not important during their formation. In contrast, mineral pairs from the quartz veins give oxygen isotopic temperatures of $\sim 440-570^{\circ} \mathrm{C}$ that are in excellent agreement with those determined from equilibria among metamorphic minerals. Minor elements characteristic to the Nagasawa deposit, in addition to $\mathrm{Mn}$ and $\mathrm{Fe}$, are those that are commonly concentrated in seafloor ferromanganese nodules. The above observations indicate that the minor elements were first scavenged by manganese oxide or hydroxide phases from seawater, pore water in deep-sea sediments, or seafloor hydrothermal fluids, were then released and incorporated in chlorite- and pyrite-bearing assemblages during the diagenetic reconstitution of manganese oxides and hydroxides to manganese carbonates, and were finally recrystallized as the minor sulfide and other minerals during contact metamorphism. The sulfur in the sulfides could have been derived from the replacement reaction of pyrite by pyrrhotite.
\end{abstract}

Keywords: bedded manganese deposits, contact metamorphism, metachert, veins, minor elements, mineralogy, oxygen isotopes, ferromanganese nodules, Nagasawa, Japan.

\section{SOMMAIRE}

Le gisement de Nagasawa, au Japon, d'âge paléozoïque à mésozoïque, contenant un amas stratifié de manganèse dans un chert, a subi les effets d'un intense métamorphisme de contact lors de la mise en place d'une venue granitique il y a entre 59 et 62 million d'années. Le minerai de manganèse se présente sous forme de silicates de manganèse stratiformes et des veines à dominance de quartz. D'après une étude pétrographique et minéralogique des échantillons de minerai, les minéraux contenant Fe,

§E-mail addresses: m-haruna@aist.go.jp, satoh-hisao@aist.go.jp, y-banno@aist.go.jp, m.bunno@aist.go.jp 
$\mathrm{Co}, \mathrm{Ni}, \mathrm{Cu}, \mathrm{Zn}, \mathrm{As}, \mathrm{Te}, \mathrm{Pb}$, et $\mathrm{Bi}$ (y inclus les éléments natifs, les sulfures, arséniures et tellurures) sont présents dans les deux types de minerai, et que la molybdénite se présente dans les veines. Ces minéraux sont étroitement associés au grenat dans des assemblages à pyroxmangite - grenat - amphibole qui se sont formés aux dépens de l'assemblage rhodochrosite - quartz chlorite, répandu dans le minerai analogue non métamorphisé. Les températures d'équilibrage fondées sur les rapports d'isotopes d'oxygène dans des paires de minéraux provenant du même échantillon de minerai stratiforme montrent des écarts importants de chaque côté de la température estimée à partir des assemblages métamorphiques. Nous attribuons la non corcordance des intervalles de température à un déséquilibre isotopique parmi les minéraux des minerais stratiformes, ce qui fait penser que l'infiltration d'une phase fluide externe n'a pas été importante lors de leur formation. En revanche, les paires de minéraux provenant des veines de quartz produisent des températures de $\sim 440-570^{\circ} \mathrm{C}$ selon les rapports des isotopes d'oxygène, et concordent bien avec celles déduites à partir des minéraux métamorphiques. Les éléments mineurs caractéristiques du gisement de Nagasawa, en plus du Mn et du Fe, sont typiques des concentrations des nodules à Fe-Mn des fonds océaniques. Dans l'ensemble, nos observations indiquent que les éléments mineurs ont d'abord été piégé par les oxydes ou hydroxydes de manganèse à partir de l'eau de mer, de l'eau des pores des sédiments marins profonds, ou bien des fluides hydrothermaux dans la croûte océanique, pour ensuite être libérés lors de la reconstitution diagénétique des oxydes et hydroxydes en carbonates de manganèse, pour se concentrer dans des assemblages à chlorite et à pyrite. Ces éléments sont finalement concentrés dans des sulfures et autres minéraux accessoires au cours d'un épisode de métamorphisme de contact. Le soufre de ces sulfures pourrait provenir de la conversion de la pyrite en pyrrhotite.

(Traduit par la Rédaction)

Mots-clés: gisement de manganèse stratiforme, métamorphisme de contact, métachert, veines, éléments mineurs, minéralogie, isotopes d'oxygène, nodules de ferromanganèse, Nagasawa, Japon.

\section{INTRODUCTION}

The bedded manganese deposits of Japan, composed mainly of manganese oxides, carbonates, and silicates, occur conformably in Paleozoic to Mesozoic marine sedimentary rocks, especially in chert, and in Miocene submarine volcanic and pyroclastic rocks (e.g., Watanabe et al. 1970). Similar manganese deposits are distributed in marine volcanosedimentary sequences, e.g., in the Franciscan Complex in California (e.g., Hein et al. 1987, Hein \& Koski 1987, Huebner \& Flohr 1990), in the Gambatesa district in eastern Liguria (Marescotti \& Frezzotti 2000), in the Proterozoic Vittinki Group in Finland (Mancini et al. 2000), and at Val Ferrera in the eastern Swiss Alps (Brugger \& Gieré 2000). Many of these deposits have been subjected to metamorphism under various conditions of temperature and pressure. Enrichment of minor elements has been recognized in such bedded manganese deposits, although they are mostly not economically important. Watanabe et al. (1970) reviewed Japanese examples and mentioned the enrichment of $\mathrm{Sr}, \mathrm{Ba}, \mathrm{B}, \mathrm{As}, \mathrm{Sb}, \mathrm{Bi}, \mathrm{Mo}, \mathrm{U}, \mathrm{Ni}$, and $\mathrm{Co}$ in the manganese ores and in their host rocks. Sugisaki et al. (1991) reported on the enrichment of $\mathrm{P}, \mathrm{Co}, \mathrm{Ni}$, $\mathrm{Cu}, \mathrm{Zn}$, and $\mathrm{Ba}$ in the rhodochrosite-rich bands developed in the Mesozoic sedimentary rocks. Exotic minerals hosting such minor elements have been described from bedded manganese deposits, especially from metamorphosed deposits. For example, As-, V-, and Sr-minerals have been reported from manganese deposits within metachert from different localities in Liguria, Italy (e.g., Marchesini \& Pagano 2001). These deposits and their host rocks have been metamorphosed under conditions of the pumpellyite-actinolite facies ( $\mathrm{T}$ in the range $300-350^{\circ} \mathrm{C}$, P between 3 and 4 kbars: Cabella et al. 2001) and the prehnite-pumpellyite facies (Cortesogno \& Lucchetti 1984, Basso et al. 1992). Brugger \& Gieré (2000) found Sb-, As-, V-, Be-, W-, REE-, Sr-, and Ba-minerals in the Swiss deposits that had undergone blueschist- to greenschist-facies metamorphism.

The origin and the processes of mobilization of the minor elements are not yet fully understood, especially in the case of granite-related contact-metamorphosed deposits. Several questions need to be addressed: Were these elements derived directly from the magmatic hydrothermal fluids? Or were they extracted from the adjacent country-rocks by the hydrothermal fluids driven by the intrusion of granitic rocks and subsequently transported to and precipitated in the manganese deposits? Or had they already been concentrated in the unmetamorphosed manganese deposits and were simply remobilized during contact metamorphism? If so, how were the minor metals incorporated in the manganese deposits?

Our objectives are to describe the geological characteristics, the parageneses, and the chemical and oxygen isotopic compositions of minerals from the contactmetamorphosed, chert-hosted bedded manganese deposit at Nagasawa, Japan. We wish to specify the chemical processes during contact metamorphism, to infer the reason for the buildup of the minor elements, and to propose a genetic model. To this end, we present field, petrographic, mineralogical, and geochemical data indicating that the manganese silicate ores and the related minerals formed during the contact metamorphism of a quartz - rhodochrosite - chlorite - pyrite assemblage, which originated from precursor manganese oxides similar to deep-sea ferromanganese nodules. 


\section{Geological Setting}

The study area is underlain by rocks of the Yamizo Group, which consists mostly of marine sedimentary rocks such as sandstone and shale of Permian to Cretaceous age (e.g., MITI 1987, Hori \& Sashida 1998). Chert, basalt and limestone also occur as small blocks or lenses, but with the exception of chert, they do not form mappable units. A relatively large chert-dominant unit is developed in the central part of the study area. Numerous manganese deposits are found conformably within rocks of the Yamizo Group, mostly in the chert unit (Fig. 1). At the northern part of the study area, rocks of the the Yamizo Group are unmetamorphosed to weakly metamorphosed, although they have been locally metamorphosed near the contact with granite. In

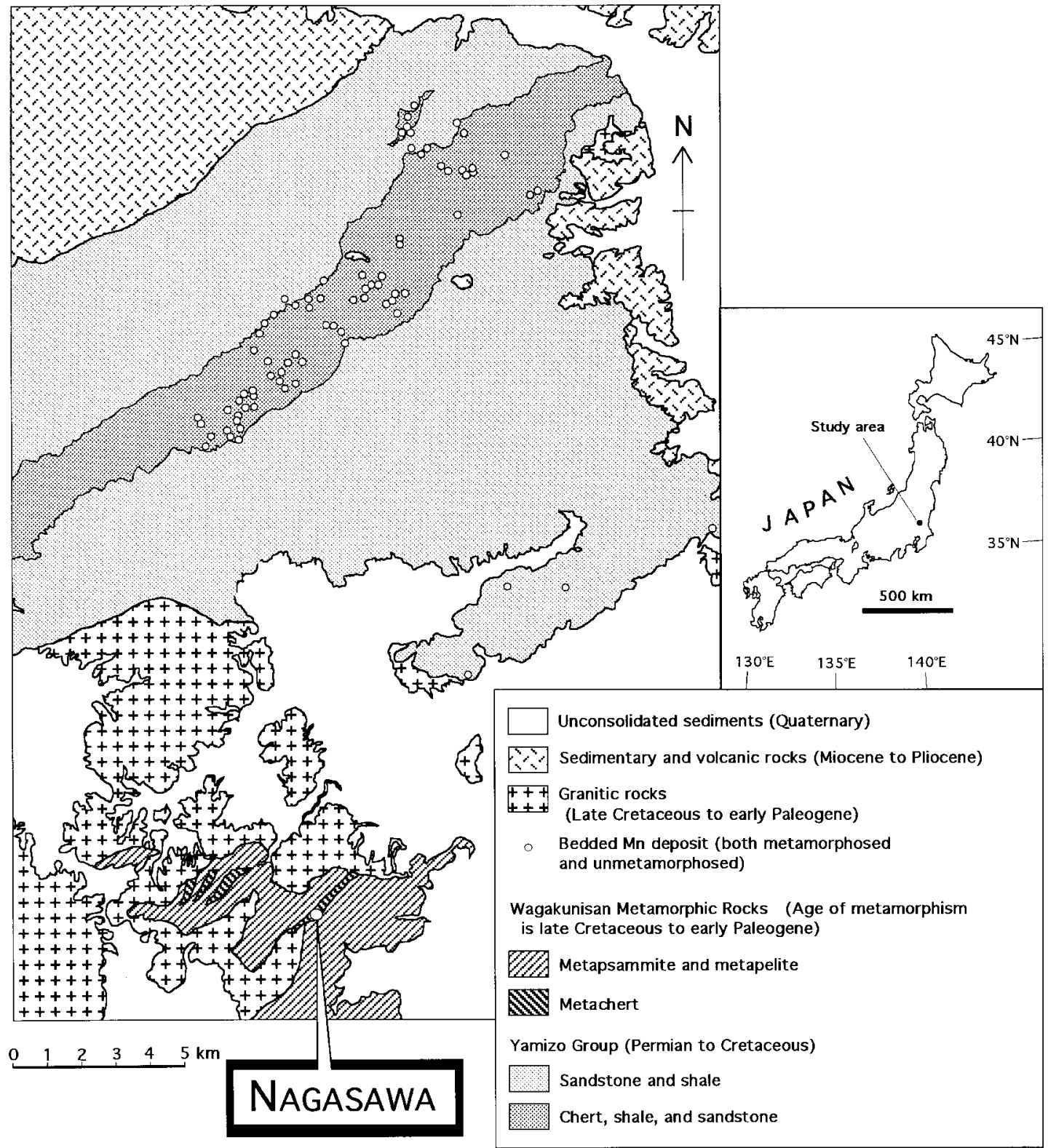

FIG. 1. Geological map around the Nagasawa deposit (from MITI 1987, Miyazaki et al. 1996). 
the southern part of the study area, the entire package of rocks has been subjected to contact metamorphism by intrusion of granitic magma $c a$. 59 to $62 \mathrm{Ma}$ ago (Kawano \& Ueda 1966, Shiba et al. 1979, Arakawa \& Takahashi 1988). Those rocks were designated by Miyazaki et al. $(1992,1996)$ as the Wagakunisan Suite of metamorphic rocks. P-T conditions of this metamorphic suite were estimated to have been $400-580^{\circ} \mathrm{C}$ and 1.5-3.0 kbar (Miyazaki et al. 1992). The emplacement of granitic magma was also responsible for the deposition of ores such as tin-tungsten veins and several tungsten skarn-type deposits (e.g., MITI 1987).

The Nagasawa bedded manganese deposit, in the southernmost part of the study area, is hosted conformably by metachert of the Wagakunisan Suite (Fig. 2), which occurs as a roof pendant in the granitic rocks near the deposit. Field evidence suggests that the Nagasawa deposit and its host metamorphic rocks underwent the most intense contact metamorphism among all the bedded manganese deposits in the study area. The minerals encountered in this suite of rocks are listed in Table 1.

\section{Modes of Occurrence of the Manganese Ore}

The manganese ores at Nagasawa occur as stratiform manganese silicates (mostly rhodonite with lesser pyroxmangite, garnet, and amphibole) conformable to the host metachert, and as cross-cutting quartz-dominant veins. The stratiform ores can be subdivided into three distinct types based on the dominant assemblages of minerals, i.e., (1) bedded rhodonite ore, (2) pyroxmangite - garnet - amphibole ore, and (3) bedded garnet biotite - apatite ore. The bedded rhodonite ore is the most abundant in the Nagasawa deposit and is composed mainly of alternating beds of rhodonite and metachert. Each bed is less than $30 \mathrm{~cm}$ in thickness and conformable with the host, unmineralized metachert. The pyroxmangite - garnet - amphibole ore is locally developed in the bedded rhodonite ore. Massive pyroxmangite and garnet are the two dominant phases (Fig. 3a). Amphibole occurs as dark green, fibrous aggregates. Sulfide minerals, mostly pyrrhotite, are disseminated in close association with garnet. The bedded garnet - biotite - apatite ore occurs in thin layers or bands that measure approximately 0.1 to $5 \mathrm{~cm}$ in thickness; it is developed locally in conformable horizons with respect to the rhodonite ore and the metachert. No clear zonal arrangement of the three types of ore from the footwall to the hanging-wall rocks has been recognized in the bedded ores, although the bedded garnet biotite - apatite ore is generally developed at the hanging-wall side of the bedded rhodonite ore.

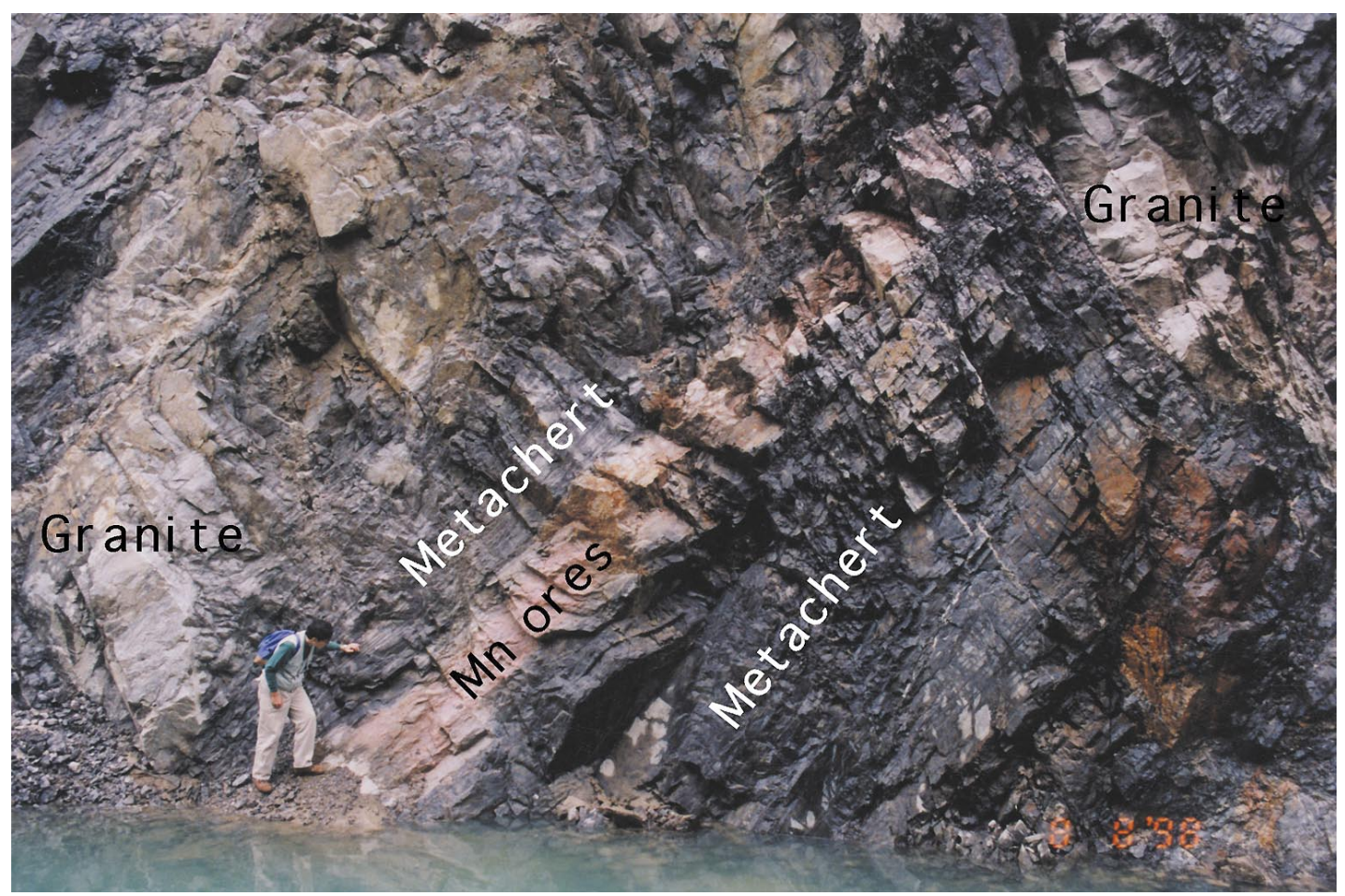

FIG. 2. Outcrop of the Nagasawa metamorphosed bedded manganese ore deposit (taken from Haruna 2001). 

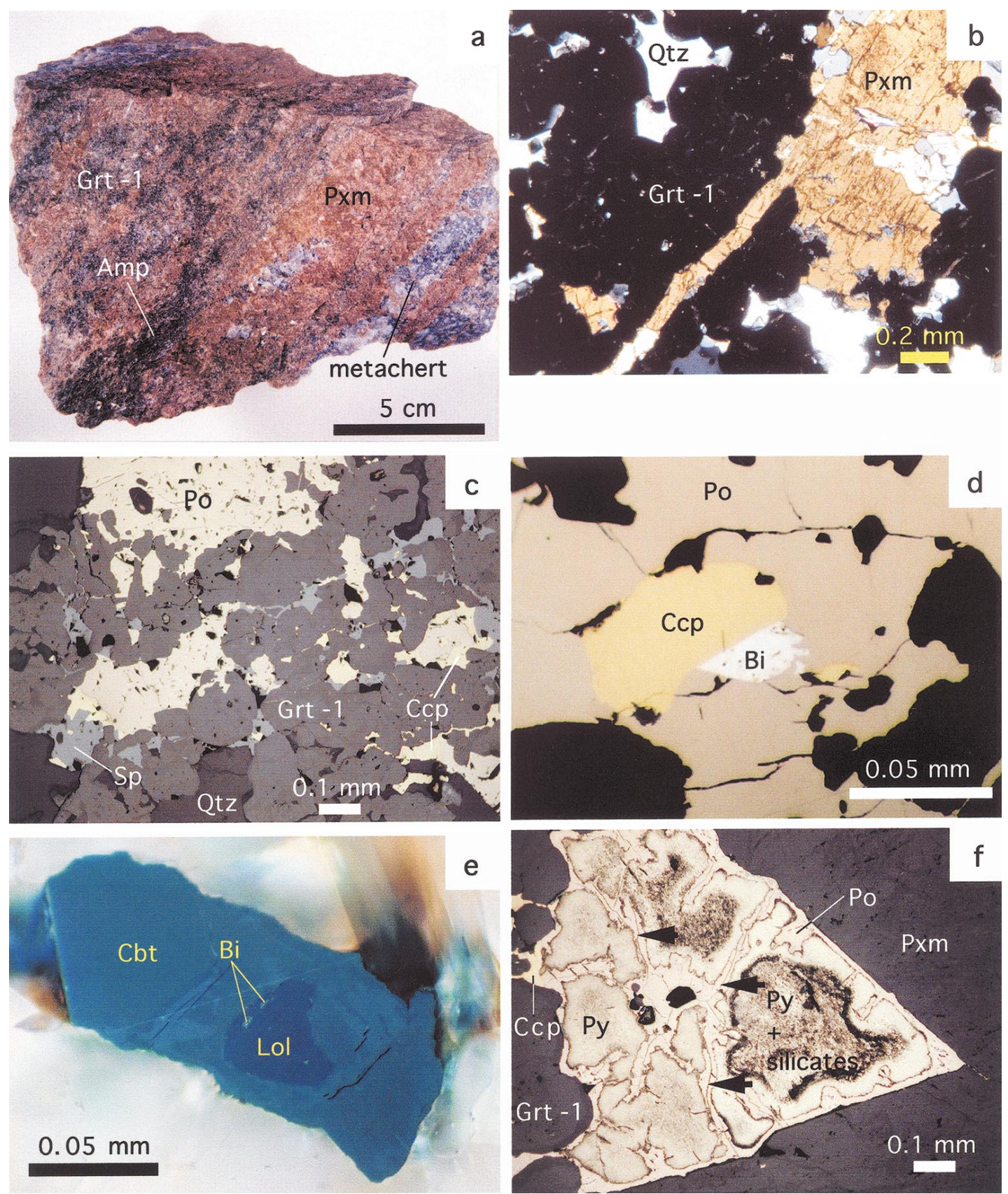

FIG. 3. Modes of occurrence of minerals from the Nagasawa deposit. The photomicrographs (b to f) were taken under reflected light, uncrossed nicols unless specified otherwise. (a) Representative hand sample of the pyroxmangite - garnet - amphibole ore. Grt-1: garnet-1 (see text and Table 2 for definition). (b) Pyroxmangite filling the interstices of garnet- 1 crystals (crossed nicols, transmitted light). (c) Pyrrhotite, chalcopyrite, and sphalerite filling the interstices of garnet-1 crystals. (d) Assemblage of pyrrhotite - chalcopyrite - native bismuth. (e) Löllingite and native bismuth included in cobaltite. Taken between slightly uncrossed nicols under reflected light. (f) Pyrite, partly admixed with very fine-grained unidentified silicate mineral(s), is veined and replaced by pyrrhotite. Note that microfractures (shown by arrows) are present along a median line of the pyrrhotite veins. 
TABLE 1. SYMBOLS OF MINERALS IN THE MANGANESE DEPOSITS AT NAGASAWA, JAPAN, AND THEIR IDEAL CHEMICAL FORMULA

\begin{tabular}{|c|c|c|}
\hline Symbol & Name & Ideal chemical formula \\
\hline Amp & amphibole (manganocummingtonite) & $\mathrm{Mn}_{2}(\mathrm{Mg}, \mathrm{Fe})_{5} \mathrm{Si}_{8} \mathrm{O}_{22}(\mathrm{OH})_{2}$ \\
\hline Ap & apatite (fluorapatite) & $\mathrm{Ca}_{5}\left(\mathrm{PO}_{4}\right)_{3}(\mathrm{~F}, \mathrm{Cl}, \mathrm{OH})$ \\
\hline Apy & arsenopyrite & FeAsS \\
\hline As & native arsenic & As \\
\hline $\mathrm{Bi}$ & native bismuth & $\mathrm{Bi}$ \\
\hline $\mathrm{Bi}(\mathrm{l})$ & liquid bismuth & $\mathrm{Bi}$ \\
\hline $\mathrm{Bi}(\mathrm{xl})$ & crystalline bismuth & $\mathrm{Bi}$ \\
\hline Bmt & bismuthinite & $\mathrm{Bi}_{2} \mathrm{\$}_{3}$ \\
\hline $\mathrm{Bt}$ & biotite (phlogopite) & $\mathrm{K}(\mathrm{Mg}, \mathrm{Fe})_{3}\left(\mathrm{Si}_{3} \mathrm{Al}\right) \mathrm{O}_{10}(\mathrm{OH}, \mathrm{F})_{2}$ \\
\hline $\mathrm{Cbt}$ & cobaltite & CoAsS \\
\hline Cep & chalcopyrite & $\mathrm{CuFeS}_{2}$ \\
\hline $\mathrm{Chl}$ & chlorite (clinochlore) & $(\mathrm{Mg}, \mathrm{Fe})_{3} \mathrm{Al}\left(\mathrm{Si}_{3} \mathrm{Al}\right) \mathrm{O}_{10}(\mathrm{OH})_{8}$ \\
\hline Gdf & gersdorffite & NiAsS \\
\hline $\mathrm{Gn}$ & galena & $\mathrm{PbS}$ \\
\hline Grt & garnet (spessartine) & $(\mathrm{Mn}, \mathrm{Fe}, \mathrm{Mg}, \mathrm{Ca})_{3} \mathrm{Al}_{2}\left(\mathrm{SiO}_{4}\right)_{3}$ \\
\hline Hdl & hedleyite & $\mathrm{Bi}_{2+x} \mathrm{Te}_{1-x}$ \\
\hline $\mathrm{Hlv}$ & helvite & $\mathrm{Mn}_{4} \mathrm{Be}_{3}\left(\mathrm{SiO}_{4}\right)_{3} \mathrm{~S}$ \\
\hline lss & intermediate solid-solution & phase in the system $\mathrm{Cu}-\mathrm{Fe}-\mathrm{S}$ \\
\hline Lol & löllingite & $\mathrm{FeAs}_{2}$ \\
\hline Mlb & molybdenite & $\mathrm{MoS}_{2}$ \\
\hline $\mathrm{Nc}$ & nickeline & NiAs \\
\hline Pn & pentlandite & $(\mathrm{Ni}, \mathrm{Fe})_{9} \mathrm{~S}_{8}$ \\
\hline Po & pyrrhotite & $\mathrm{Fe}_{1-x} \mathrm{~S}$ \\
\hline Prk & parkerite & $\mathrm{Ni}_{3} \mathrm{Bi}_{2} \mathrm{~S}_{2}$ \\
\hline Pxm & pyroxmangite & $\mathrm{MnSiO}_{3}$ \\
\hline Py & pyrite & $\mathrm{FeS}_{2}$ \\
\hline Pyf & pyrophanite & $\mathrm{MnTiO}_{3}$ \\
\hline Qtz & quartz & $\mathrm{SiO}_{2}$ \\
\hline Rdn & rhodonite & $\mathrm{MnSiO}_{3}$ \\
\hline Rds & thodochrosite & $\mathrm{MnCO}_{3}$ \\
\hline $\mathrm{Sp}$ & sphalerite & $(\mathrm{Zn}, \mathrm{Fe}) \mathrm{S}$ \\
\hline
\end{tabular}

The symbols listed above appear in the text, figures and tables. In parentheses ${ }_{2}$ we list the name of the species corresponding to the formula shown.

The quartz-dominant veins, most of which clearly intersect both the bedded ores and the host rocks, contain the following minerals, in decreasing order of abundance: quartz, garnet, amphibole, apatite, biotite, pyrrhotite, chalcopyrite, pyrite, pyrophanite, and molybdenite. The quartz crystals in veins are much coarsergrained and hence look whiter and more glassy than those in the metachert, and euhedral crystals up to $2 \mathrm{~cm}$ in length are locally observed. All the other minerals in the veins occur only in minor amounts, although amphibole, apatite, biotite, and pyrrhotite are locally abundant. Amphibole is abundant, both in the rhodonite beds and in the veins, near the bedded ore - vein contact. Veinlets of amphibole clearly cross-cutting rhodonite are commonly observed. The occurrence of molybdenite is restricted to the quartz veins.

Three distinct types of garnet have been recognized at the Nagasawa deposit on the basis of their mode of occurrence in the three types of ore (Table 2). The first type, designated as garnet-1 hereafter, occurs as a major constituent of the pyroxmangite - garnet - amphibole ore. Grains of garnet-1 are fine grained (less than $0.5 \mathrm{~mm}$ in diameter), massive, greenish gray in color, and closely associated with pyroxmangite, amphibole, and accessory minerals. The second type (garnet-2) occurs in the garnet - biotite - apatite ore that is devel- oped conformably with the bedding plane. The third type (garnet-3) is the most abundant and occurs as a constituent of the veins.

No silica-undersaturated minerals, such as tephroite and manganosite, have been observed in either the ore beds or the veins, suggesting that quartz was stable throughout the history of the contact metamorphism.

\section{Mineralogy, Paragenesis, AND Mineral Compositions}

\section{General}

The mineralogy and paragenesis at the Nagasawa deposit were investigated by macroscopic observation of ores both in outcrops and in hand specimens, and by examination of polished ore chips and polished thin sections with reflected and transmitted light microscopes, and with a scanning electron microscope.

Contact metamorphism at the Nagasawa deposit can be divided into two stages, i.e., the metamorphism of the bedded ores (the rhodonite horizons, the pyroxmangite - garnet - amphibole, and the bedded garnet - biotite - apatite ores) and subsequently, the formation of veins. Aside from grain sizes and relative modal percentages, mineralogy and paragenesis in the bedded ores and the veins are similar, although several differences have been recognized, e.g., no pyroxenoids in the veins, and no molybdenite in the bedded ores. The anhydrous manganese silicates (pyroxmangite, rhodonite, and garnet), apatite, and pyrophanite formed prior to the sulfide minerals, which commonly fill the interstices

TABLE 2. COMPARISON OF THE TYPES OF GARNET IN THE NAGASAWA DEPOSIT, JAPAN

\begin{tabular}{llll}
\hline & Garnet-1 & Garnet-2 & Gamet-3 \\
\hline Ore type & Pxm-Grt-Amp ore & Grt-Bt-Ap ore & Grt-Qtz vein \\
Form & Massive & $\begin{array}{l}\text { Thin layer } \\
\text { conformable to } \\
\text { the bedding plane }\end{array}$ & $\begin{array}{l}\text { Selvage and } \\
\text { monomineralic } \\
\text { band or discrete } \\
\text { crystals }\end{array}$ \\
& & & $<10$ mm \\
Grain size & $<0.5$ mm & $<1$ mm & Qtz, Ap, Bt \\
Associated & Amp, Pxm, Qtz, & Bt, Ap, Qtz & \\
minerals & minor minerals & & $\begin{array}{l}\text { Brownish red } \\
\text { to orange }\end{array}$ \\
Color & Greenish gray & $\begin{array}{l}\text { Orange to } \\
\text { orange brown }\end{array}$ & 18 \\
& & 16 & $45.5-65.7(55.9)$ \\
No. of analyses & 11 & $44.4-61.6(55.9)$ & $19.9-43.4(29.0)$ \\
Mole\% sps & $75.1-88.5(82.4)$ & $19.7-41.5(28.6)$ & $2.8-10.6(4.2)$ \\
Mole\% alm & $3.8-17.4(9.6)$ & $5.7-11.0(7.7)$ & $3.0-13.6(11.0)$ \\
Mole \% prp & $2.1-3.0(2.3)$ & $2.4-11.6(7.7)$ & \\
Mole \% grs & $4.3-6.8(5.7)$ & &
\end{tabular}

Garnet end-members considered: spessartine (sps), almandine (alm), pyrope (prp) and grossular (grs). Mole percent of each end-member is given with range and average (in parentheses). "Minor minerals" are defined in the text. 
among the silicate crystals and fill cracks and cleavages in them. Iron sulfides (pyrrhotite and pyrite), nickelcobalt minerals (pentlandite, cobaltite, gersdorffite, nickeline, and cobaltian löllingite), bismuth minerals (native bismuth, hedleyite, parkerite, and bismuthinite), chalcopyrite, sphalerite, galena, and molybdenite have been identified as minor minerals. Representative textures are shown in Figure 3 (b to $\mathrm{f}$ ), and a general paragenetic sequence of minerals is given in Figure 4.

Chemical analyses of rhodonite, pyroxmangite, garnet, amphibole, pyrite, pyrrhotite, cobaltite, pentlandite, gersdorffite, nickeline, sphalerite, hedleyite, and parkerite were made using a JEOL JXA 8800R electron microprobe at the Geological Survey of Japan. Conditions for the major-element analysis were $15 \mathrm{kV}$ acceleration potential, $12 \mathrm{nA}$ beam current, $2 \mu \mathrm{m}$ beam diameter and counting times of 20 seconds for each element and 10 seconds for background. For $\mathrm{F}$ and $\mathrm{Cl}, \mathrm{F}-$ substituted phlogopite $\left(\mathrm{KMg}_{3} \mathrm{AlSi}_{3} \mathrm{O}_{10} \mathrm{~F}_{2}\right)$ and $\mathrm{RbCl}$ crystals, both synthetic, were used as standards for each element, with a pulse-height analyzer (e.g., Sato et al. 1997), and counting times for each of the two elements were 40 seconds. The signals obtained were corrected by the ZAF method.

\section{Garnet}

Chemical compositions of garnet are given in Table 3 and Figure 5. Site allocation of cations and the calculation of end-member compositions (in mole \%) were done according to the method of Deer et al. (1992). All three types, i.e., garnet-1, 2, and 3, are spessartinerich, with considerable $\mathrm{Fe}, \mathrm{Mg}$, and $\mathrm{Ca}$ contents, although garnet- 1 contains less $\mathrm{Fe}, \mathrm{Mg}$, and $\mathrm{Ca}$ than the other two types, which are comparable in chemical composition to each other.

\section{Rhodonite and pyroxmangite}

Two species of pyroxenoid, rhodonite and pyroxmangite, were identified in the Nagasawa deposit. Both minerals occur as massive aggregates and are pinkish to brownish in color, although pyroxmangite in this deposit is generally darker and coarser-grained (up to $3 \mathrm{~cm}$ in size) than rhodonite. They are very similar in appearance and thus hard to distinguish. Distinction and identification were made by X-ray diffraction (XRD) on powdered samples of monomineralic separates handpicked from representative samples of ore. The polished

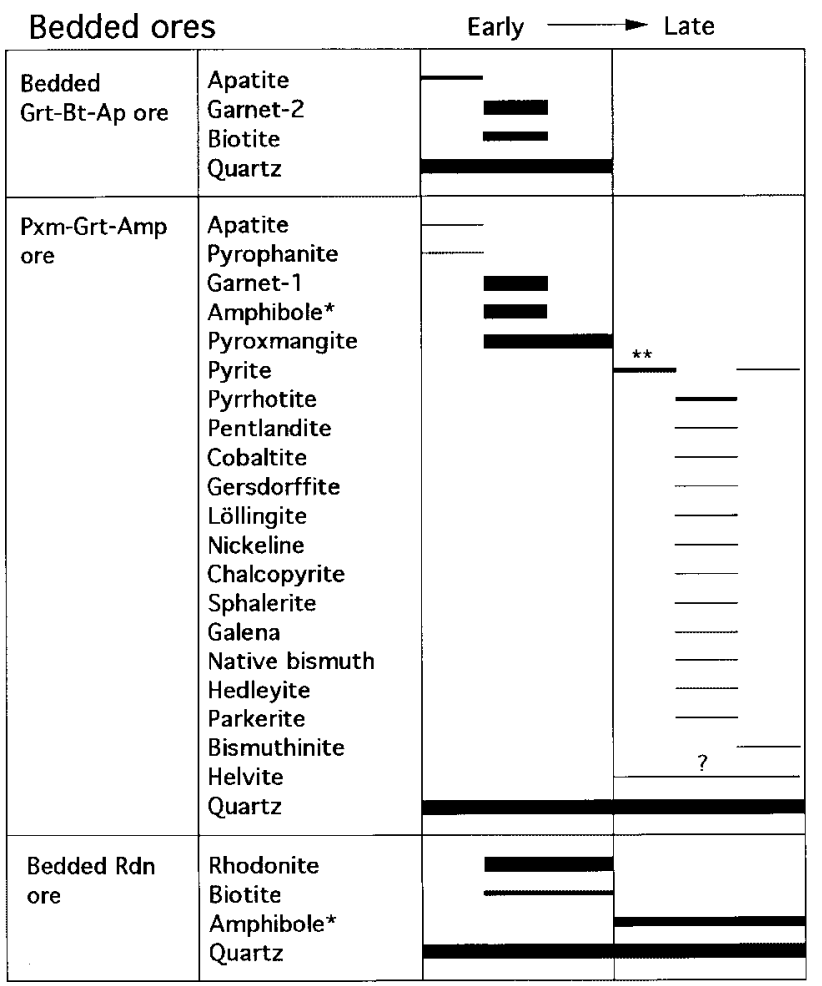

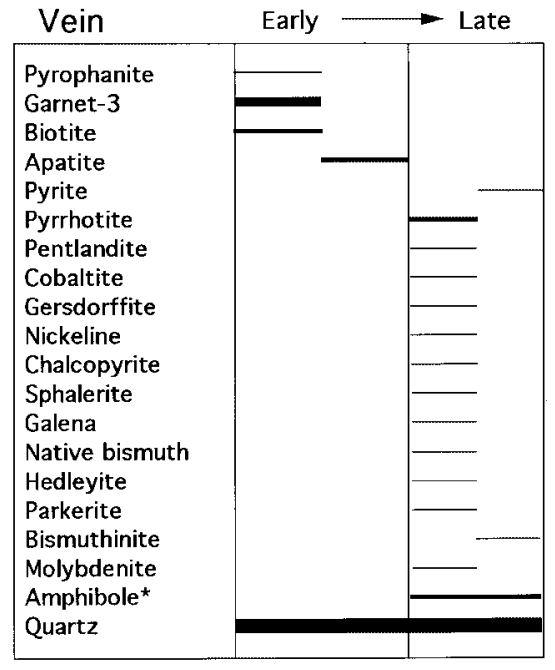

* Manganocummingtonite - manganogrunerite ** or inherited from the protolith

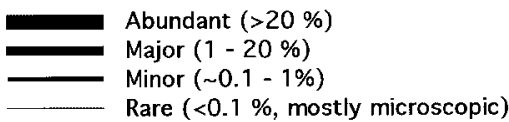

FIG. 4. General paragenetic sequence and relative modal abundances of minerals in the Nagasawa deposit. 
thin sections were prepared from the samples selected for XRD analysis. Preliminary measurements of the optic axial angles $(2 \mathrm{~V})$ of several crystals of each mineral species were conducted to ensure the identity of each phase identified by XRD. The measured $2 V$ values were 30 to $48^{\circ}$ for six crystals of pyroxmangite and 70 and $86^{\circ}$ for two crystals of rhodonite. Those results are consistent with the previously reported $2 \mathrm{~V}$ values, e.g., 37 to $45^{\circ}$ for pyroxmangite and 63 to $87^{\circ}$ for rhodonite (Deer et al. 1992). Rhodonite is the major constituent of the bedded rhodonite ore, whereas pyroxmangite occurs in the pyroxmangite - garnet - amphibole ore. Pyroxmangite is closely associated and mostly contemporaneous with garnet-1 and amphibole, although occurrences of pyroxmangite in interstices among garnet-1 crystals suggest that the formation of pyroxmangite also continued after the formation of garnet-1 (Fig. 3b). Both pyroxenoids contain appreciable amounts of $\mathrm{Fe}, \mathrm{Mg}$, and $\mathrm{Ca}$ along with $\mathrm{Mn}$. The two minerals are chemically distinct; pyroxmangite contains more $\mathrm{Fe}$ and less
Ca than rhodonite, but they show comparable Mg contents (Table 3, Fig. 6).

\section{Amphibole}

We have recognized two generations of amphibole. One is closely associated and contemporaneous with pyroxmangite and garnet in the pyroxmangite - garnet - amphibole ore (Fig. 3a), and the other is developed near the contact between the bedded ores and the veins and is contemporaneous with the veins. Both generations occur as fibrous aggregates and show oblique extinction indicating their symmetry to be monoclinic. All the $\mathrm{Fe}$ in amphibole is considered as $\mathrm{Fe}^{2+}$ since stoichiometric constraints are satisfied, i.e., Si and total cations are almost equal to 8 and 15 atoms per formula unit (apfu), respectively, for most of the samples (Table 3). On the basis of their compositions and monoclinic symmetry, the amphibole corresponds to manganocummingtonite and manganogrunerite. Amphibole in the

TABLE 3. REPRESENTATIVE RESULTS OF ELECTRON-MICROPROBE ANALYSES OF SILICATES FROM THE NAGASAWA DEPOSIT, JAPAN

\begin{tabular}{|c|c|c|c|c|c|c|c|c|c|c|c|c|c|}
\hline Mineral & Grt-1 & Grt-1 & Grt-2 & Grt-2 & Grt-3 & Grt-3 & Pxm & Pxm & $\operatorname{Rdn}$ & Rdn & Amp & Amp & d. 1 . \\
\hline $\mathrm{SiO}_{2}$ wt $\%$ & 35.9 & 36.2 & 37.0 & 36.9 & 36.8 & 37.1 & 46.8 & 47.3 & 47.7 & 47.1 & 51.7 & 51.4 & 0.02 \\
\hline $\mathrm{TiO}_{2}$ & 0.75 & 0.42 & 0.33 & 0.01 & 0.58 & 0.24 & $<$ d. 1 . & 0.02 & $<\mathrm{d} .1$ & 0.01 & 0.02 & 0.01 & 0.02 \\
\hline $\mathrm{Al}_{2} \mathrm{O}_{3}$ & 20.5 & 20.9 & 21.2 & 21.3 & 21.0 & 21.2 & $<$ d. 1. & $<$ d.l. & $<\mathrm{d} .1$. & $<\mathrm{d} .1$ & 0.05 & 0.05 & 0.01 \\
\hline $\mathrm{Cr}_{2} \mathrm{O}_{3}$ & $<\mathrm{d} .1$ & $<\mathrm{d} .1$ & $<$ d.l. & 0.04 & $<\mathrm{d} .1$ & $<$ d.. . & $<$ d. 1 . & $<$ d.l. & $<\mathrm{d} .1$ & $<\mathrm{d} .1$ & $<$ d.l. & $<$ d.I. & 0.02 \\
\hline $\mathrm{FeO}^{\mathrm{a}}$ & 4.53 & 1.67 & 8.26 & 17.1 & 8.79 & 19.1 & 12.7 & 15.1 & 3.28 & 7.86 & 17.8 & 20.5 & 0.03 \\
\hline $\mathrm{MnO}$ & 35.2 & 37.9 & 29.0 & 20.8 & 28.7 & 19.8 & 35.9 & 33.1 & 42.3 & 38.3 & 14.5 & 13.9 & 0.02 \\
\hline $\mathrm{MgO}$ & 0.58 & 0.56 & 2.13 & 2.71 & 1.80 & 1.50 & 2.99 & 3.54 & 3.07 & 2.38 & 12.1 & 10.5 & 0.02 \\
\hline $\mathrm{CaO}$ & 1.70 & 1.83 & 2.23 & 0.86 & 2.45 & 1.71 & 1.43 & 1.35 & 3.59 & 3.98 & 0.55 & 0.53 & 0.02 \\
\hline $\mathrm{Na}_{2} \mathrm{O}$ & $<\mathrm{d} .1$ & $<$ d.l. & $<\mathrm{d} .1$ & $<$ d.l. & $<\mathrm{d} .1$ & $<$ d.I. & 0.02 & 0.02 & $<\mathrm{d} .1$ & $<$ d.l. & 0.03 & 0.04 & 0.01 \\
\hline $\mathrm{K}_{2} \mathrm{O}$ & $<$ d. 1 & $<\mathrm{d} .1$ & $<$ d.l. & $<$ d.1. & $<\mathrm{d} .1$. & $<\mathrm{d} .1$. & $<\mathrm{d} .1$ & $<\mathrm{d} .1$ & $<$ d.1. & $<$ d. 1 & $<\mathrm{d} .1$ & $<\mathrm{d} .1$ & 0.01 \\
\hline Total & 99.2 & 99.4 & 100.1 & 99.7 & 100.1 & 100.6 & 99.8 & 100.4 & 99.9 & 99.6 & $96.7^{*}$ & 96.9 & \\
\hline
\end{tabular}

Number of cations on the basis of given number of oxygen atoms

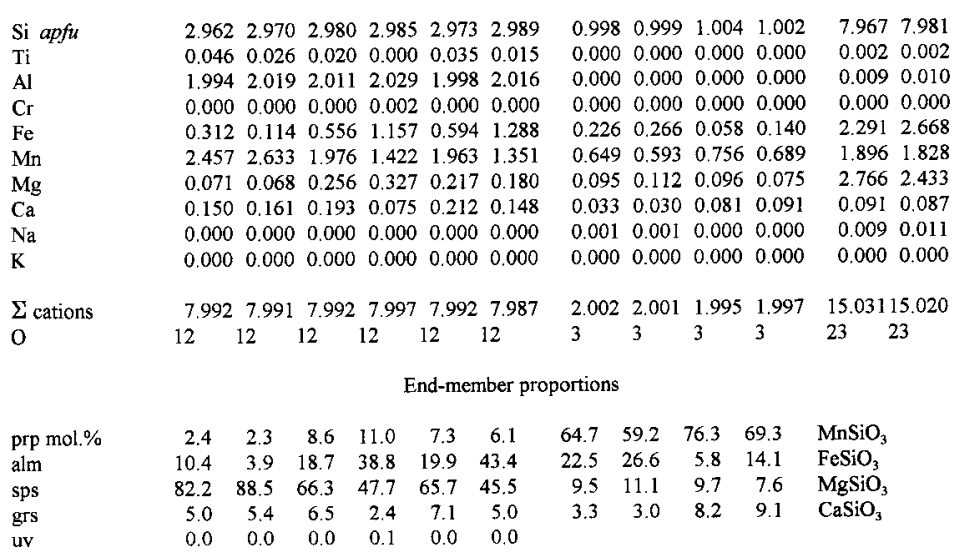

$\mathrm{FeO}^{\mathrm{a}}$ : Total iron expressed as $\mathrm{FeO} ;<\mathrm{d} .1$ : below detection limit. * Includes $0.01 \mathrm{wt} . \% \mathrm{Cl}$. The two amphibole samples have $\mathrm{Fe}^{2+} /\left(\mathrm{Mg}+\mathrm{Fe}^{2+}\right)$ values of 0.45 and 0.52 , respectively. Garnet end-members: see Table 2; uv: uvarovite. 

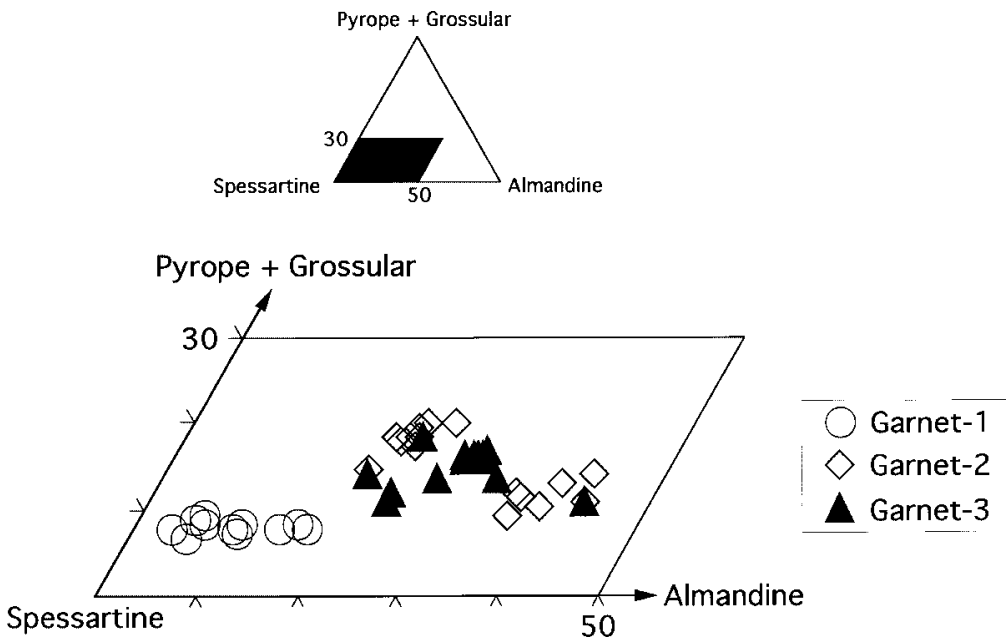

FIG. 5. Chemical compositions (in mole \%) of garnet from the Nagasawa deposit.
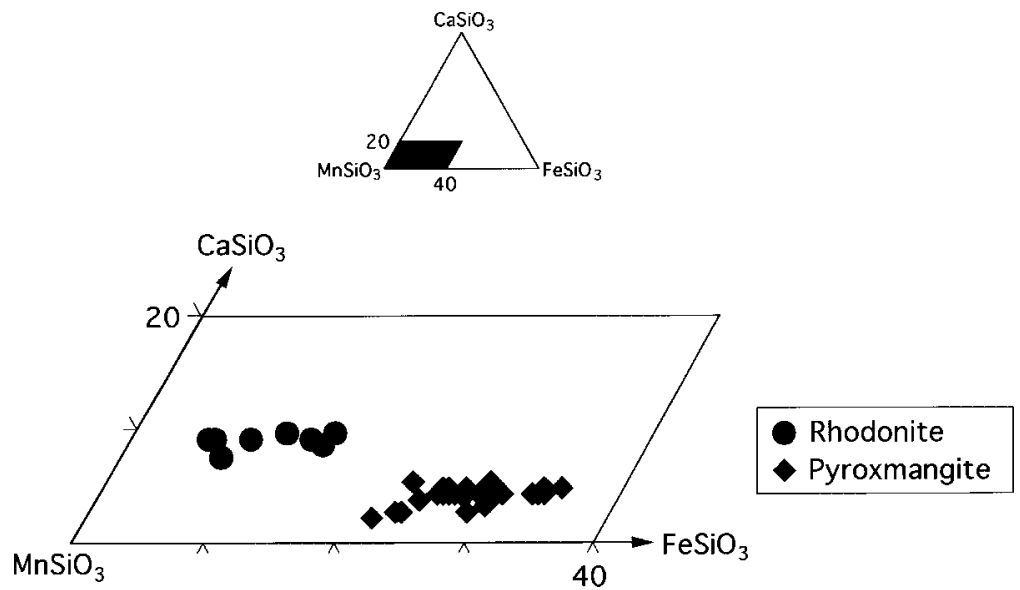

FIG. 6. Chemical compositions (in mole \%) of pyroxmangite and rhodonite from the Nagasawa deposit.

pyroxmangite - garnet - amphibole ore contains more $\mathrm{Fe}$ and less $\mathrm{Ca}$ than that in the veins (Fig. 7).

\section{Minor minerals}

Pyrrhotite is the most abundant sulfide mineral in the Nagasawa deposit. This mineral is mostly disseminated in the bedded ores, along with other sulfide minerals such as chalcopyrite and sphalerite, and fills the interstices of the silicates, especially garnet-1 (Fig. 3c). Massive pyrrhotite up to several centimeters in size is occasionally observed in the veins. Pyrrhotite in the pyroxmangite - garnet - amphibole ore is strongly mag- netic and shows a close association with pyrite, which indicates that this pyrrhotite is monoclinic, whereas pyrrhotite in the veins is nonmagnetic, and thus hexagonal (Craig \& Scott 1974). Pyrrhotite in the pyroxmangite - garnet - amphibole ore contains minor amounts of Ni (up to $1.2 \mathrm{wt} \%$; Table 4).

Pyrite is much less abundant than pyrrhotite and is observed mostly in the pyroxmangite - garnet - amphibole ore and in the veins. Pyrite in the ore mostly occurs as an aggregate of extremely fine-grained crystals, partly admixed with silicate minerals that are too fine-grained to be identified even with the electron microprobe, and hence shows poorly polished surfaces in reflected light. 
Pyrite is commonly veined and replaced by pyrrhotite. Microfractures, partly healed with pentlandite, are widely developed along median lines of the pyrrhotite veinlets (Fig. 3f). Pyrite in the pyroxmangite - garnet amphibole ore contains a minor amount of $\mathrm{Ni}$ ( 0.1 wt.\%: Table 4), considerably less than pyrrhotite. Pyrite in the veins is coarser grained and occurs commonly as well-formed crystals of cubic habit.

$\mathrm{Ni}$ - and Co-minerals are widely distributed in the ores in the Nagasawa deposit, i.e., pentlandite, cobaltite, gersdorffite, nickeline, and cobaltian löllingite (Table 4, Fig. 8). They are mostly less than $200 \mu \mathrm{m}$ in size except cobaltite, which is generally larger than the other Ni- and Co-minerals. Pentlandite occurs mostly as lamellae in pyrrhotite, although it rarely occurs as discrete grains associated with pyrrhotite, chalcopyrite and other nickel minerals. The Co content of pentlandite is low $(<0.2 \mathrm{wt} . \%)$. Cobaltite occurs as composite grains of intergrown euhedral to subhedral crystals and rarely includes smaller grains of native bismuth,
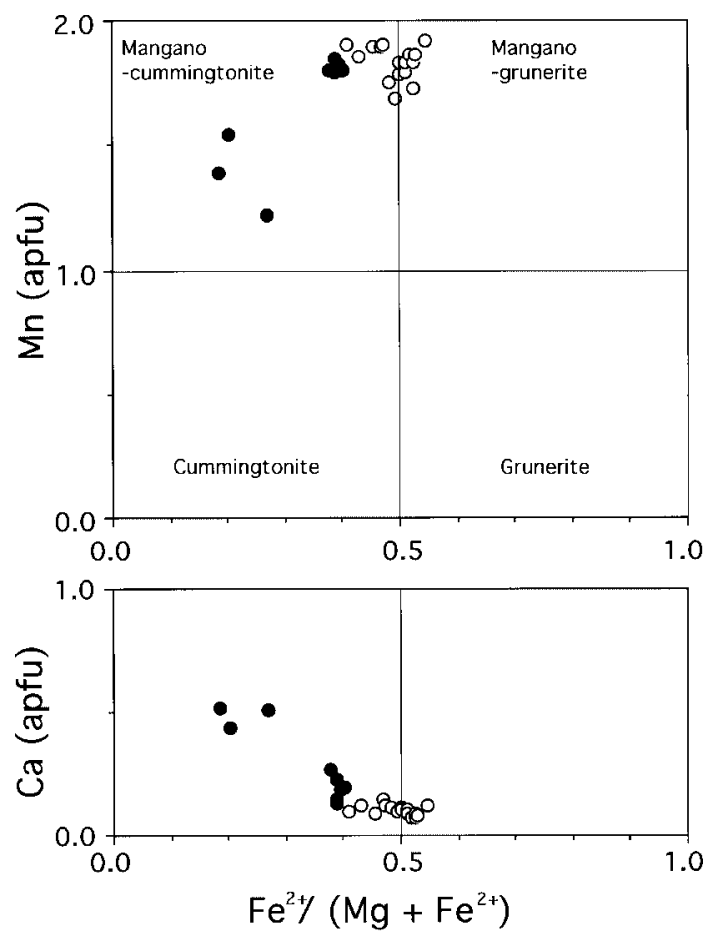

O in Pxm-Grt-Amp ore

in veins

FIG. 7. Chemical compositions of amphibole from the Nagasawa deposit. The nomenclature and site allocation of cations follow Leake et al. (1997). bismuthinite and, more rarely, löllingite. Cobaltite shows a wide range in $\mathrm{Ni}$ and $\mathrm{Fe}$ contents, up to 12.4 wt.\% $\mathrm{Ni}$ and $7.0 \mathrm{wt} \%$ Fe. Gersdorffite occurs as euhedral to subhedral crystals with nickeline and pyrrhotite, and contains an appreciable amount of Co (up to 11.4 wt.\%) and $\mathrm{Fe}$ (up to 4.5 wt.\%). Nickeline is associated with pyrrhotite, pentlandite, gersdorffite, native bismuth, and parkerite. The $\mathrm{Co}$ and $\mathrm{Fe}$ contents of nickeline are much lower than those of cobaltite and gersdorffite (less than $0.6 \mathrm{wt} . \%$ for both elements). Small amounts (mostly less than $0.2 \mathrm{wt} . \%$ ) of S, Sb and $\mathrm{Te}$ were detected, as well as $\mathrm{Ni}, \mathrm{Fe}, \mathrm{Co}$, and $\mathrm{As}$.

The common occurrence of bismuth minerals is another characteristic of the Nagasawa deposit. Native bismuth, bismuthinite, hedleyite, and parkerite were recognized under reflected light and identified by electron microprobe (Table 5). Native bismuth is the most abundant mineral of bismuth, occurring as small (mostly less than $100 \mu \mathrm{m}$ ) masses with pyrrhotite, nickeline, and other bismuth minerals. Occasionally, an assemblage of native bismuth - chalcopyrite - pyrrhotite also is observed (Fig. 3d). Both hedleyite and parkerite are closely associated and show mutual boundaries with native bismuth. Bismuthinite commonly rims or veins native bismuth and is considered to be a later product of sulfidation.

Sphalerite is closely associated with other sulfides, especially pyrrhotite and chalcopyrite, and fills the interstices of and fractures in the crystals of garnet-1 (Fig. $3 \mathrm{c})$. It contains appreciable amounts of $\mathrm{Fe}$, ranging from 15.8 to 21.0 mole \% FeS (Table 6). Mn and Cd (1.1 and $0.4 \mathrm{wt} . \%$ on average, respectively) were also found as minor constituents.

\section{OXYGEN ISOTOPES}

Oxygen isotopic compositions of monomineralic separates of garnet, pyroxenoids, amphibole, and quartz (both from metachert and vein) were measured using the laser fluorination method established by Sharp (1990). Details of the method employed in this study are given in Satoh (2000) and Mancini et al. (2000). The results are shown in Table 7 and Figure 9.

Vein garnet (garnet-3) is subdivided here into types $3 \mathrm{~A}$ and $3 \mathrm{~B}$ on the basis of mode of occurrence and grain size. Garnet-3A forms vein selvages or thin monomineralic bands consisting of finer-grained crystals (less than $1 \mathrm{~mm}$ across), whereas garnet-3B occurs as larger, discrete crystals of up to $10 \mathrm{~mm}$ across. The $\delta^{18} \mathrm{O}$ values range from +12.5 to $+13.8 \%$ o for rhodonite (two samples), +12.8 to $+13.6 \%$ o for garnet- $3 \mathrm{~A}$ (two samples), +10.2 to $+10.9 \%$ o for garnet- $3 \mathrm{~B}$ (six samples), +10.7 to $+16.1 \%$ o for vein quartz (eight samples), and +14.5 to $+24.1 \%$ for metachert (five samples). The $\delta^{18} \mathrm{O}$ values of pyroxmangite, garnet-2, and vein amphibole are $+12.2,+12.9$, and $+11.6 \%$, respectively. The analytical uncertainty is approximately $\pm 0.13 \%$ o for each single measurement (Satoh 2000). The $\delta^{18} \mathrm{O}$ values of vein quartz are lower than those of host metachert in 
two samples. The order of $\delta^{18} \mathrm{O}$ values of various minerals in the same sample are consistent with the equilibrium order, i.e., $\delta^{18} \mathrm{O}_{\text {garnet }}<\delta^{18} \mathrm{O}_{\text {pyroxmangite and rhodonite }}<$ $\delta^{18} \mathrm{O}_{\text {amphibole }}<\delta^{18} \mathrm{O}_{\text {quartz }}($ e.g., Zheng 1993a, b), except for one pair of vein quartz and garnet-3A, which shows the reversed order of ${ }^{18} \mathrm{O}$ enrichment (sample 98032102). The $\delta^{18} \mathrm{O}$ values of garnet-3B and vein quartz, and hence the observed oxygen isotopic fractionation-factors $(\Delta)$

\begin{tabular}{|c|c|c|c|c|c|c|c|c|c|c|c|c|c|c|}
\hline Mineral & Py & Po & Po & Pn & $\mathrm{Cbt}$ & Cbt & Lol & d. $l$. & & Gdf & Gdf & $\mathrm{Nc}$ & $\mathrm{Nc}$ & d. 1 \\
\hline $\mathrm{Fe}$ wt. $\%$ & 47.2 & 59.8 & 61.5 & 32.1 & 6.21 & 5.54 & 14.3 & 0.03 & $\mathrm{Fe}$ & 4.52 & 3.60 & 0.15 & 0.49 & 0.03 \\
\hline Co & $<\mathrm{d} .1$. & $<\mathrm{d} . \mathrm{l}$ & $<$ d.1. & 3.03 & 19.3 & 18.1 & 9.28 & 0.03 & $\mathrm{Co}$ & 11.4 & 2.49 & 0.32 & 0.51 & 0.03 \\
\hline $\mathrm{Ni}$ & 0.13 & 0.64 & 0.37 & 30.8 & 10.4 & 11.9 & 5.09 & 0.04 & $\mathrm{Ni}$ & 19.6 & 29.6 & 45.4 & 44.1 & 0.04 \\
\hline $\mathrm{S}$ & 52.5 & 38.9 & 38.2 & 33.4 & 19.8 & 17.5 & 0.30 & 0.02 & $S$ & 19.1 & 19.1 & 0.11 & 0.12 & 0.02 \\
\hline \multirow[t]{2}{*}{ As } & 0.16 & $<\mathrm{d} .1$ & $<$ d. 1 . & $<$ d. 1. & 43.8 & 46.5 & 70.5 & 0.04 & As & 44.3 & 44.4 & 53.9 & 54.2 & 0.04 \\
\hline & & & & & & & & & $\mathrm{Mn}$ & 0.66 & $<\mathrm{d} .1$ & $<\mathrm{d} .1$ & $<\mathrm{d} .1$ & 0.03 \\
\hline \multirow[t]{2}{*}{ Total } & 100.1 & 99.3 & 100.0 & 99.3 & 99.6 & 99.5 & 99.5 & & $\mathrm{Sb}$ & $<$ d.l. & 0.33 & 0.13 & 0.21 & 0.03 \\
\hline & & & & & & & & & $\mathrm{Te}$ & 0.13 & $<\mathrm{d} .1$ & 0.17 & 0.13 & 0.03 \\
\hline & & & & & & & & & Total & 99.7 & 99.5 & 100.2 & 99.7 & \\
\hline
\end{tabular}

Number of atoms on the basis of given number of $S$ or $S+$ As atoms

\begin{tabular}{|c|c|c|c|c|c|c|c|c|c|c|c|c|}
\hline \multicolumn{2}{|c|}{$\Sigma \mathrm{S}\left({ }^{*} \mathrm{~S}+\mathrm{As}\right) 2$} & 8 & 8 & 8 & 1 & 1 & $2^{*}$ & \multirow[b]{2}{*}{$\mathrm{Fe}$} & \multirow{2}{*}{$\begin{array}{c}1 \\
0.14\end{array}$} & \multirow{2}{*}{$\begin{array}{c}1 \\
0.11\end{array}$} & \multirow{2}{*}{$\begin{array}{c}1^{*} \\
0.00\end{array}$} & \multirow{2}{*}{$\begin{array}{c}1^{*} \\
0.01\end{array}$} \\
\hline Fe $a p f u$ & 1.03 & 7.06 & 7.40 & 4.42 & 0.18 & 0.18 & 0.54 & & & & & \\
\hline $\mathrm{Co}$ & & & & 0.40 & 0.53 & 0.56 & 0.33 & $\mathrm{Co}$ & 0.33 & 0.07 & 0.01 & 0.01 \\
\hline $\mathrm{Ni}$ & 0.00 & 0.07 & 0.04 & 4.04 & 0.29 & 0.37 & 0.18 & $\mathrm{Ni}$ & 0.56 & 0.85 & 1.07 & 1.04 \\
\hline \multirow[t]{4}{*}{ As } & 0.00 & & & & 0.95 & 1.14 & & As & 0.99 & 1.00 & & \\
\hline & & & & & & & & $\mathrm{Mn}$ & 0.02 & & & 0.00 \\
\hline & & & & & & & & $\mathrm{Sb}$ & & 0.00 & 0.00 & 0.00 \\
\hline & & & & & & & & Te & 0.00 & & 0.00 & 0.00 \\
\hline $\begin{array}{l}\Sigma(\mathrm{Fe}+ \\
\mathrm{Co}+\mathrm{Ni})\end{array}$ & 1.03 & 7.13 & 7.45 & 8.85 & 1.00 & 1.12 & 1.05 & & 1.02 & 1.03 & 1.09 & 1.06 \\
\hline
\end{tabular}

$<$ d.1.: below detection limit. apfu: atoms per formula unit.

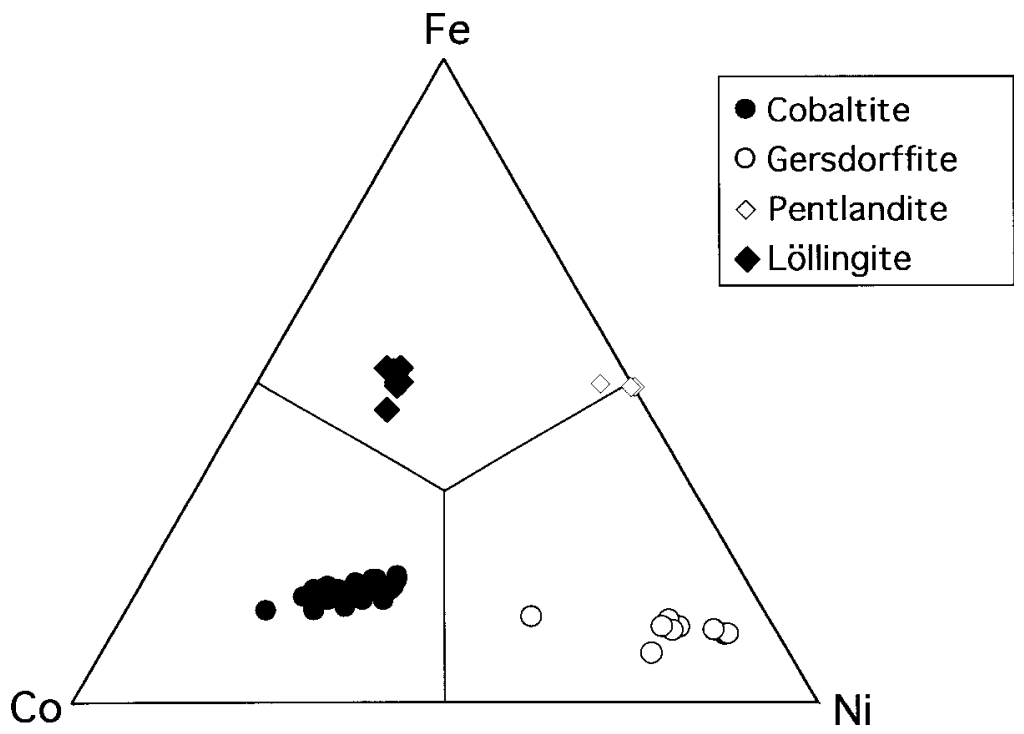

FIG. 8. Chemical compositions (in atomic ratio of $\mathrm{Fe}, \mathrm{Co}$, and $\mathrm{Ni}$ ) of cobaltite, gersdorffite, löllingite, and pentlandite from the Nagasawa deposit. 
between those two minerals from the same samples, are quite uniform except for one datum for vein quartz $\left(\delta^{18} \mathrm{O}\right.$ $=+10.7 \%$, sample 98032102). On the other hand, the values obtained from metachert are highly variable.

\section{DISCUSSION}

\section{Protoliths and chemical processes in contact metamorphism}

The bedded ores at the Nagasawa deposit are classified into three types, i.e., (1) bedded rhodonite ore, (2) pyroxmangite - garnet - amphibole ore, and (3) bedded garnet - biotite - apatite ore. The protoliths and dominant chemical processes for the formation of each ore type are discussed below.

Bedded rhodonite ore: The most probable protolith of this ore type is a stratiform manganese carbonate ore in which rhodochrosite and quartz were the two predominant phases. This conclusion is supported by the mineralogy of the unmetamorphosed to weakly metamorphosed bedded manganese deposits in the Yamizo Group, which mainly comprises rhodochrosite (MITI 1987). Similar rhodochrosite-rich manganese deposits have been recognized in chert-dominant sequences in the marine sedimentary rocks in Japan, most of which are of Mesozoic age. Sugisaki et al. (1991) studied the rhodochrosite-rich lenses or nodules from several localities in the Mino Belt, a province comparable in lithology and tectonic setting to the Yamizo Group, and designated those lenses as "manganese bands." The "manganese bands" are composed mainly of spherulitic to massive rhodochrosite in a siliceous or argillaceous matrix. Those characteristics are common to many unmetamorphosed stratiform rhodochrosite-rich ores

TABLE 5. REPRESENTATIVE RESULTS OF ELECTRON-MICROPROBE ANALYSES OF HEDLEYITE AND PARKERITE FROM THE NAGASAWA DEPOSIT, JAPAN

\begin{tabular}{|c|c|c|c|c|c|c|c|}
\hline Mineral & Hdl & Hdl & d.l. & & Prk & Prk & d.1. \\
\hline Bi wt. \% & 81.3 & 81.2 & 0.05 & $\mathbf{N} i$ & 27.8 & 28.0 & 0.05 \\
\hline $\mathrm{Te}$ & 17.7 & 17.5 & 0.04 & $\mathrm{Bi}$ & 62.9 & 63.3 & 0.05 \\
\hline $\mathrm{Fe}$ & 0.2 & 50.2 & 10.04 & $S$ & 9.86 & 9.66 & 0.02 \\
\hline $\mathrm{Se}$ & 0.16 & 0.19 & 0.03 & $\mathrm{Sb}$ & 0.35 & 0.34 & 0.04 \\
\hline $\mathrm{Sb}$ & 0.14 & 0.11 & 0.04 & & & & \\
\hline $\mathrm{Pb}$ & 0.27 & $<\mathrm{d} .1$ & 0.06 & Total & 100.9 & 101.3 & \\
\hline Total & 99,8 & 99.2 & & & & & \\
\hline $\mathrm{Bi}$ atom \% & 72.5 & 73.0 & & $\mathrm{Ni}$ & 43.6 & 44.0 & \\
\hline $\mathrm{Te}$ & 25.8 & 25.7 & & $\mathrm{Bi}$ & 27.8 & 27.9 & \\
\hline $\mathrm{Fe}$ & 0.84 & 0.69 & & $S$ & 28.4 & 27.7 & \\
\hline $\mathrm{Se}$ & 0.38 & 0.45 & & Sb & 0.27 & 0.26 & \\
\hline Sb & 0.21 & 0.17 & & & & & \\
\hline $\mathrm{Pb}$ & 0.24 & & & $\mathrm{Ni} /(\mathrm{Bi}+\mathrm{Sb})$ & 1.55 & 1.56 & \\
\hline & & & & $\mathrm{Ni} / \mathrm{S}$ & 1.54 & 1.59 & \\
\hline $\mathrm{Bi} / \mathrm{Te}$ & 2.81 & 2.84 & & & & & \\
\hline
\end{tabular}

$<$ d.l: below detection limit. hosted by chert-dominant sequences (e.g., Matsumoto 1987, Momoi et al. 1988).

The chemical composition of rhodonite, the most abundant manganese mineral in the Nagasawa deposit, is approximately $\left(\mathrm{Mn}_{0.7} \mathrm{Fe}^{2+}{ }_{0.1} \mathrm{Mg}_{0.1} \mathrm{Ca}_{0.1}\right) \mathrm{SiO}_{3}$ (Table 3, Fig. 6). This mineral is considered to have formed by the reaction between rhodochrosite and excess quartz:

$$
\begin{aligned}
& \left(\mathrm{Mn}_{0.7} \mathrm{Fe}^{2+}{ }_{0.1} \mathrm{Mg}_{0.1} \mathrm{Ca}_{0.1}\right) \mathrm{CO}_{3}+\mathrm{SiO}_{2} \rightarrow \\
& \mathrm{Rds} \quad \mathrm{Qtz} \\
& \left(\mathrm{Mn}_{0.7} \mathrm{Fe}^{2+}{ }_{0.1} \mathrm{Mg}_{0.1} \mathrm{Ca}_{0.1}\right) \mathrm{SiO}_{3}+\mathrm{CO}_{2} \\
& \text { Rdn }
\end{aligned}
$$

as suggested also by Sugisaki et al. (1991).

Pyroxmangite - garnet - amphibole ore: Average chemical compositions of garnet-1, amphibole, and pyroxmangite in this type of ore can be given as $\left(\mathrm{Mn}_{2.7} \mathrm{Fe}^{2+}{ }_{0.3}\right) \mathrm{Al}_{2} \mathrm{Si}_{3} \mathrm{O}_{12}, \mathrm{Mn}_{2}\left(\mathrm{Mg}_{2.6} \mathrm{Fe}^{2+}{ }_{2.4}\right) \mathrm{Si}_{8} \mathrm{O}_{22}$ $(\mathrm{OH})_{2}$, and $\left(\mathrm{Mn}_{0.7} \mathrm{Fe}^{2+}{ }_{0.3}\right) \mathrm{SiO}_{3}$, respectively (Table 3, Figs. 5 to 7). In order to produce these minerals, precursor minerals containing $\mathrm{Mg}, \mathrm{Fe}^{2+}$, and $\mathrm{Al}$ as major constituents are necessary in addition to rhodochrosite and quartz. A chlorite-group mineral is the most reasonable candidate for such a mineral; in fact, Matsumoto (1987) identified chlorite as a minor constituent in unmetamorphosed nodules of rhodochrosite from a chert-dominant sequence in Japan. Momoi et al. (1988) identified clay minerals enclosing spherulitic rhodochrosite from the Komaoka mine, Japan, as interlayered chloritesaponite. Huebner \& Flohr (1990) listed several minerals including rhodochrosite, quartz, and chlorite (both

\begin{tabular}{|c|c|c|c|c|}
\hline & 1 & 2 & 3 & d.l. \\
\hline Zn wt.\% & 55.3 & 52.6 & 51.7 & 0.06 \\
\hline $\mathrm{Fe}$ & 9.08 & 11.4 & 12.3 & 0.03 \\
\hline $\mathrm{Mn}$ & 0.55 & 1.56 & 1.39 & 0.16 \\
\hline $\mathrm{Cd}$ & 0.21 & 0.57 & 0.41 & 0.03 \\
\hline $\mathrm{Cu}$ & 0.60 & $<$ d.1. & 0.42 & 0.05 \\
\hline $\mathrm{S}$ & 33.6 & 33.8 & 33.4 & 0.02 \\
\hline Total & 99.3 & 99.9 & 99.6 & \\
\hline \multicolumn{5}{|c|}{ Number of atoms on the basis of one atom of sulfur } \\
\hline Zn apfiu & 0.81 & 0.76 & 0.76 & \\
\hline $\mathrm{Fe}$ & 0.16 & 0.19 & 0.21 & \\
\hline $\mathrm{Mn}$ & 0.01 & 0.03 & 0.02 & \\
\hline $\mathrm{Cd}$ & 0.00 & 0.00 & 0.00 & \\
\hline $\mathrm{Cu}$ & 0.01 & & 0.01 & \\
\hline Total & 0.98 & 0.99 & 1.01 & \\
\hline $\mathrm{ZnS}$ mole $\%$ & 82.1 & 77.2 & 75.6 & \\
\hline $\mathrm{FeS}$ & 15.8 & 19.6 & 21.0 & \\
\hline $\mathrm{MnS}$ & 1.0 & 2.7 & 2.4 & \\
\hline $\mathrm{CdS}$ & 0.2 & 0.5 & 0.3 & \\
\hline $\mathrm{CuS}$ & 0.9 & & 0.6 & \\
\hline
\end{tabular}
clinochlore and pennantite) as the precursors of the

TABLE 6. REPRESENTATIVE RESULTS OF ELECTRON-MICROPROBE ANALYSES OF SPHALERITE FROM THE NAGASAWA DEPOSIT, JAPAN 


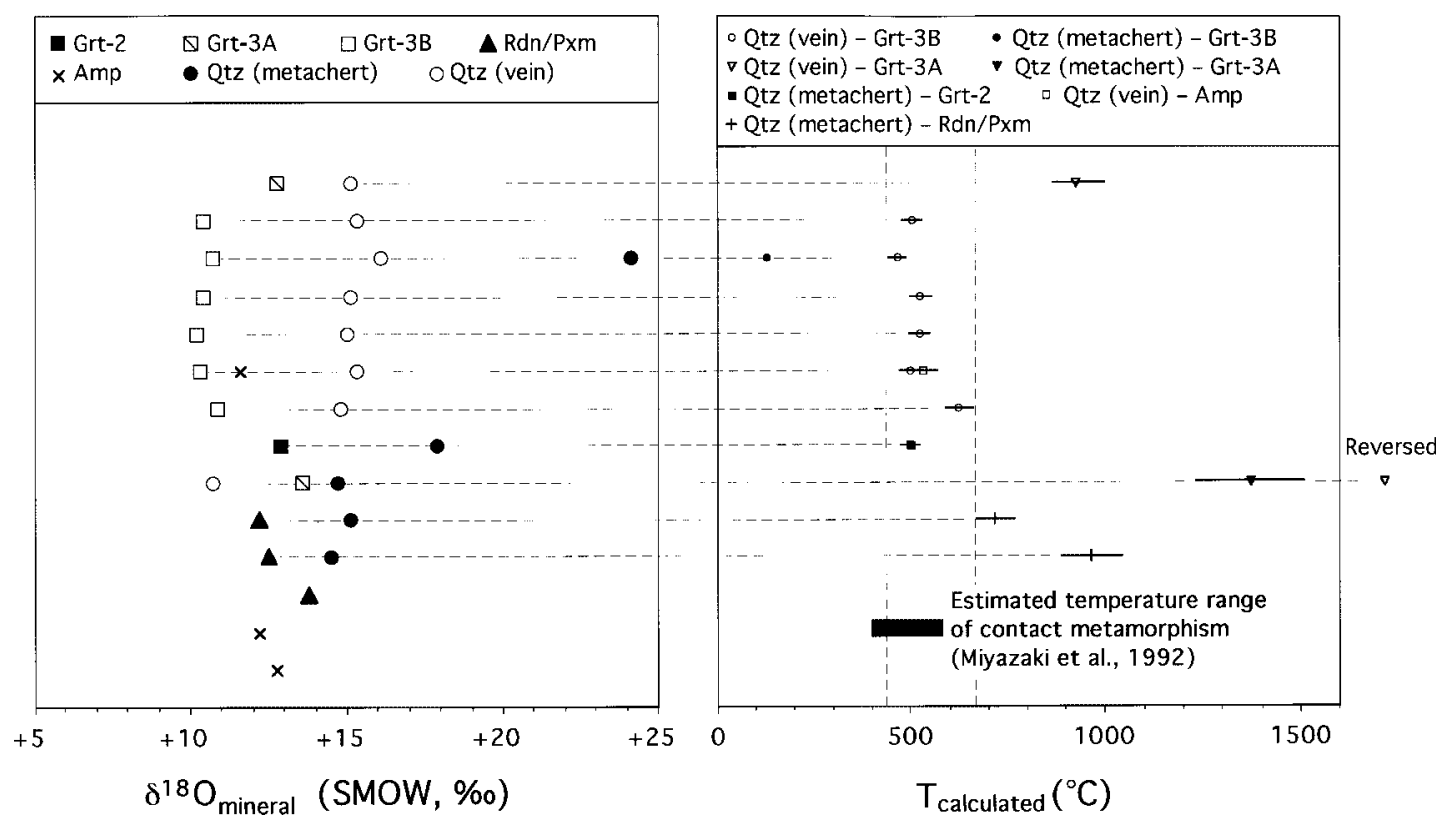

FIG. 9. Measured $\delta^{18} \mathrm{O}$ values of garnet, pyroxmangite, rhodonite, amphibole, and quartz (from both vein and metachert) from the Nagasawa deposit and the calculated temperatures. The $\delta^{18} \mathrm{O}$ values of coexisting minerals separated from the same hand sample and the temperatures calculated from those minerals are shown as symbols connected by a dashed tie-line.

Buckeye deposit in the Franciscan Complex, California. The authors cited indicate that a chlorite-group mineral occurs ubiquitously in unmetamorphosed manganese carbonate ores. A possible reaction for the formation of garnet- 1 and amphibole is:

$$
\begin{aligned}
& 687\left(\mathrm{Mn}_{0.7} \mathrm{Fe}^{2+}{ }_{0.3}\right) \mathrm{CO}_{3}+ \\
& \text { Rds } \\
& 87\left(\mathrm{Mg}_{3.7} \mathrm{Fe}^{2+}{ }_{1.3}\right) \mathrm{Al}\left(\mathrm{Si}_{3} \mathrm{Al}\right) \mathrm{O}_{10}(\mathrm{OH})_{8}+984 \mathrm{SiO}_{2} \\
& \rightarrow 87\left(\mathrm{Mn}_{2.7} \mathrm{Fe}^{2+}{ }_{0.3}\right) \mathrm{Al}_{2} \mathrm{Si}_{3} \mathrm{O}_{12}+ \\
& \text { Grt-1 } \\
& 123 \mathrm{Mn}_{2}\left(\mathrm{Mg}_{2.6} \mathrm{Fe}^{2+}{ }_{2.4}\right) \mathrm{Si}_{8} \mathrm{O}_{22}(\mathrm{OH})_{2}+687 \mathrm{CO}_{2} \\
& +225 \mathrm{H}_{2} \mathrm{O} \\
& \text { Amp }
\end{aligned}
$$

When the chlorite, less abundant than rhodochrosite and quartz in the unmetamorphosed ore, was exhausted by the above reaction or where no chlorite was available during contact metamorphism, pyroxmangite formed instead of garnet- 1 and amphibole.

$$
\begin{gathered}
\left(\mathrm{Mn}_{0.7} \mathrm{Fe}^{2+}{ }_{0.3}\right) \mathrm{CO}_{3} \\
\mathrm{Rds}+\mathrm{SiO}_{2} \rightarrow \\
\mathrm{Qtz}_{\left(\mathrm{Mn}_{0.7} \mathrm{Fe}^{2+}{ }_{0.3}\right) \mathrm{SiO}_{3}}+\mathrm{CO}_{2} \\
\mathrm{Pxm}
\end{gathered}
$$

The formation of pyroxmangite continued until rhodochrosite was completely consumed. The sequence of reactions is consistent with the petrographic observation that pyroxmangite veins occasionally fill the interstices of garnet-1 crystals (Fig. 3b).

Bedded garnet - biotite - apatite ore: In this ore, garnet-2, quartz, and biotite are dominant constituents. Garnet-2 and biotite may have formed from the assemblage of rhodochrosite, quartz, chlorite, and potassiumbearing minerals. Potassium-bearing minerals in unmetamorphosed manganese carbonate ores include illite and K-feldspar (e.g., Matsumoto 1987, Sugisaki et al. 1991). Those minerals and chlorite are the most likely sources of all the $\mathrm{K}, \mathrm{Al}$, and of considerable proportions of $\mathrm{Fe}^{2+}$ and $\mathrm{Mg}$ in garnet- 2 and biotite.

\section{Oxygen isotopic constraints on the source of the minor elements and the vein formation}

Detailed mineralogical examination revealed that $\mathrm{Co}, \mathrm{Ni}, \mathrm{Cu}, \mathrm{Zn}, \mathrm{As}, \mathrm{Mo}, \mathrm{Te}, \mathrm{Pb}$, and $\mathrm{Bi}$ are the minor elements that characterize the Nagasawa polymetallic deposit. In order to evaluate the possibility that those minor elements were transported by external hydrothermal fluids to the manganese deposit, analogous to ore-bearing skarns where metals such as $\mathrm{Cu}$ are hydrothermally added to the host skarn (e.g., Haruna et al. 1990, Haruna \& Ohmoto 1996), temperatures of oxygen isotope equilibration were calculated for the mineral pairs formed by quartz (from both vein and 
metachert) and the following minerals: garnet, pyroxmangite, rhodonite, and amphibole. These mineral pairs were obtained from the same samples, and their measured oxygen isotopic compositions were used in conjunction with the theoretical fractionation-factors of Zheng (1993a, b). The fractionation factors between quartz and several end-member minerals (spessartine, rhodonite, and cummingtonite) were employed for the pairs of quartz-garnet, quartz-pyroxenoids (rhodonite and pyroxmangite), and quartz-amphibole, respectively, although the manganese silicate minerals in Nagasawa contain appreciable amounts of $\mathrm{Fe}^{2+}, \mathrm{Mg}$, and $\mathrm{Ca}$ (Tables 2,3). Replacement of $\mathrm{Mn}^{2+}$ by those divalent cations does not change the fractionation factors significantly. For example, equilibrium fractionations between end-member spessartine and almandine and between rhodonite and $\mathrm{Fe}$-substituted rhodonite $\left(\mathrm{FeSiO}_{3}\right)$ at $500^{\circ} \mathrm{C}$ are calculated to be only $\sim 0.07$ and $\sim 0.04 \%$, respectively (Zheng 1993a). Lichtenstein \& Hoernes
(1992) also recognized a lack of fractionation of oxygen isotopes among the pyralspite group of garnets. Mancini et al. (2000) applied the fractionation factor of Zheng (1993b) between quartz and cummingtonite to their pairs of quartz and Mn-bearing amphibole and obtained reasonable temperatures.

The calculated oxygen isotopic temperatures for the mineral pairs obtained from the bedded ores (four pairs including metachert) are widely scattered, from 130 to $1370^{\circ} \mathrm{C}$. They include the temperature range of contact metamorphism of the Wagakunisan metamorphic rocks, $400-580^{\circ} \mathrm{C}$, estimated by Miyazaki et al. (1992) from the mineral equilibria in metapelitic rocks (Table 7 , Fig. 9). The discrepancy in temperature ranges between that estimated by the mineral equilibria and that by the oxygen isotopic compositions is probably due to the lack of oxygen isotopic equilibrium among the coexisting minerals on a hand-specimen scale during contact metamorphism. Rather, the oxygen isotopic compositions

TABLE 7. MEASURED $\delta^{18}$ O VALUES OF GARNET, PYROXENOIDS (PYROXMANGITE AND RHODONITE), AND QUARTZ (FROM BOTH VEIN AND HOST METACHERT), NAGASAWA DEPOSIT, AND CALCULATED OXYGEN ISOTOPIC TEMPERATURES

\begin{tabular}{|c|c|c|c|c|}
\hline Sample & Sample description & Mineral & (SMOW, \%) & Isotopic $\mathrm{T}\left({ }^{\circ} \mathrm{C}\right)$ \\
\hline 98080803 & $\begin{array}{l}\text { Apatite - garnet - quartz vein } \\
\text { cross-cutting host metachert }\end{array}$ & $\begin{array}{l}\text { Garnet-3A } \\
\text { Quartz (vein) }\end{array}$ & $\begin{array}{l}+12.8 \\
+15.1\end{array}$ & $930 \pm 70($ Vein Qtz - Grt $-3 A)$ \\
\hline 98020402 & $\begin{array}{l}\text { Garnet - quartz vein } \\
\text { cross-cutting host metachert }\end{array}$ & $\begin{array}{l}\text { Garnet-3B } \\
\text { Quartz (vein) }\end{array}$ & $\begin{array}{l}+10.4 \\
+15.3\end{array}$ & $500 \pm 30($ Vein Qtz - Grt-3B) \\
\hline $98032101-\mathrm{C}$ & $\begin{array}{l}\text { Garnet - quartz vein } \\
\text { cross-cutting host metachert }\end{array}$ & $\begin{array}{l}\text { Garnet-3B } \\
\text { Quartz (vein) } \\
\text { Quartz (metachert) }\end{array}$ & $\begin{array}{l}+10.7 \\
+16.1 \\
+24.1\end{array}$ & $\begin{array}{l}460 \pm 20(\text { Vein Qtz }- \text { Grt }-3 B) \\
130 \pm 10(\text { Metachert }- \text { Grt-3B) }\end{array}$ \\
\hline 98032102 & $\begin{array}{l}\text { Garnet - quartz vein } \\
\text { cross-cutting host metachert }\end{array}$ & $\begin{array}{l}\text { Garnet-3A } \\
\text { Quartz (vein) } \\
\text { Quartz (metachert) }\end{array}$ & $\begin{array}{l}+13.6 \\
+10.7 \\
+14.7\end{array}$ & $\begin{array}{l}\text { Reversed (Vein Qtz - Grt-3A) } \\
1370 \pm 140 \text { (Metachert - Grt-3A) }\end{array}$ \\
\hline M33886 & $\begin{array}{l}\text { Massive, brownish pyroxmangite } \\
\text { and garnet interbedded with } \\
\text { metachert }\end{array}$ & $\begin{array}{l}\text { Pyroxmangite } \\
\text { Quartz (metachert) }\end{array}$ & $\begin{array}{l}+12.2 \\
+15.1\end{array}$ & $720 \pm 50($ Metachert - Pxm) \\
\hline 98020403 & $\begin{array}{l}\text { Fine-grained, orange garnet } \\
\text { interbedded with metachert }\end{array}$ & $\begin{array}{l}\text { Garnet-2 } \\
\text { Quartz (metachert) }\end{array}$ & $\begin{array}{l}+12.9 \\
+17.9\end{array}$ & $500 \pm 30($ Metachert - Grt -2$)$ \\
\hline 98080804 & $\begin{array}{l}\text { Massive, pinkish rhodonite } \\
\text { interbedded with metachert }\end{array}$ & $\begin{array}{l}\text { Rhodonite } \\
\text { Quartz (metachert) }\end{array}$ & $\begin{array}{l}+12.5 \\
+14.5\end{array}$ & $970 \pm 80$ (Metachert - Rdn $)$ \\
\hline 98020404 & $\begin{array}{l}\text { Massive, brownish rhodonite } \\
\text { interbedded with metachert }\end{array}$ & Rhodonite & +13.8 & \\
\hline MK-1 & $\begin{array}{l}\text { Garnet - quartz vein cross- } \\
\text { cutting metachert }\end{array}$ & $\begin{array}{l}\text { Garnet-3B } \\
\text { Quartz (vein) }\end{array}$ & $\begin{array}{l}+10.4 \\
+15.1\end{array}$ & $530 \pm 30($ Vein Qtz - Grt-3B $)$ \\
\hline MK-2 & $\begin{array}{l}\text { Apatite - garnet - quartz vein } \\
\text { cross-cutting massive } \\
\text { amphibole and garnet }\end{array}$ & $\begin{array}{l}\text { Garnet-3B } \\
\text { Quartz (vein) }\end{array}$ & $\begin{array}{l}+10.2 \\
+15.0\end{array}$ & $520 \pm 30($ Vein Qtz - Grt-3B $)$ \\
\hline $\mathrm{MK}-3$ & $\begin{array}{l}\text { Amphibole - garnet - quartz } \\
\text { vein cross-cutting bedded } \\
\text { thodonite ore }\end{array}$ & $\begin{array}{l}\text { Garnet-3B } \\
\text { Quartz (vein) } \\
\text { Amp }\end{array}$ & $\begin{array}{l}+10.3 \\
+15.3 \\
+11.6\end{array}$ & $\begin{array}{l}500 \pm 30(\text { Vein Qtz }- \text { Grt-3B }) \\
530 \pm 40(\text { Vein Qtz }- \text { Amp) } \\
410 \pm 80(\text { Amp - Grt }-3 B)\end{array}$ \\
\hline $\mathrm{MK}-4$ & Garnet - quartz vein & $\begin{array}{l}\text { Garnet-3B } \\
\text { Quartz (vein) }\end{array}$ & $\begin{array}{l}+10.9 \\
+14.8\end{array}$ & $620 \pm 40($ Vein Qtz - Grt-3B $)$ \\
\hline
\end{tabular}


were controlled by those of the protoliths at the Nagasawa deposit. Establishment of oxygen isotopic equilibrium via fluid media may be expected among metamorphic minerals on the scale of a few meters, if they formed under fluid-dominant conditions (Hayashi \& Ohmoto 1996) or underwent post-metamorphic events under fluid-dominant conditions, e.g., hydrothermal alteration. In addition, all of the $\delta^{18} \mathrm{O}$ values of the minerals from the bedded ores, i.e., rhodonite, pyroxmangite, garnet- 2 , and metachert, fall in the range of those of the typical metasediments, +8 to $+26 \%$ o (Sheppard 1986). The high and variable nature of $\delta^{18} \mathrm{O}$ values of the bedded ores indicates that the oxygen isotopic compositions were inherited from those of the original sedimentary rocks (Taylor 1974, Hayashi \& Ohmoto 1996). We contend that no externally derived fluids with lower $\delta^{18} \mathrm{O}$ values reacted with the bedded ores to homogenize the oxygen isotopic compositions of minerals. The possibility of hydrothermal input of the minor elements to the bedded ores can thus be ruled out. On the contrary, those elements are considered to have been concentrated in the manganese ores before contact metamorphism. They were simply precipitated in the form of minor minerals from $\mathrm{H}_{2} \mathrm{O}$ - and $\mathrm{CO}_{2}$-rich fluids produced by the metamorphic devolatilization-type reactions and remained along grain boundaries of earlierformed minerals such as pyroxenoids, garnet, and amphibole. The nature of mineralization in this type of manganese deposits is in contrast to what is observed in the ore-bearing skarns, where externally derived hydrothermal fluids carried the ore metals (e.g., Haruna et al. 1990, Haruna \& Ohmoto 1996). The replacement of carbonates (rhodochrosite or calcite) by silicates (manganese silicates or calc-silicates), however, is the dominant process of formation in both types of ore deposits.

In contrast to the bedded ores, the temperatures of the vein stage estimated from the oxygen isotopic fractionation between vein quartz and garnet-3B (six pairs) and between vein quartz and amphibole (one pair) fall in a range of $440-660^{\circ} \mathrm{C}$ (mostly $440-570^{\circ} \mathrm{C}$ ). Those values are in excellent agreement with the temperatures of contact metamorphism estimated by Miyazaki et al. (1992). This agreement in temperatures between the veins and the host metamorphic rocks implies that the vein minerals attained oxygen isotopic equilibrium with each other (except garnet-3A) and that the veins formed during the peak stage of contact metamorphism, i.e., the estimated temperatures for the veins are also applicable to the bedded ores.

Vein quartz and garnet-3A (two pairs) are not in oxygen isotopic equilibrium, i.e., one pair gives an unreasonably high temperature of $930^{\circ} \mathrm{C}$, and the other shows reversed relationship in terms of ${ }^{18} \mathrm{O}$ enrichment (Table 7). We interpret garnet-3A as having originally formed as garnet- 2 that was later incorporated in the vein as xenocrysts. This view is supported by the comparable oxygen isotopic compositions of garnet-2 and garnet-3A (Table 7, Fig. 9). Garnet-3B probably origi- nated from garnet-3A and was subsequently recrystallized, and equilibrated with the vein-forming fluid.

The $\delta^{18} \mathrm{O}$ values of $\mathrm{H}_{2} \mathrm{O}$ in equilibrium with the minerals in the bedded ores and in the veins at the inferred temperatures of vein formation range from +10.7 to $+21.7 \%$ o (mostly to $+16.3 \%$ o) and from +11.9 to $+13.1 \%$, respectively. Those values seem to fall in a similar range, although the former values are more variable. However, oxygen isotopic fractionation was recognized between the vein quartz and its host metachert in two samples (98032101-C and 98032102), i.e., the $\delta^{18} \mathrm{O}$ values of vein quartz are lower than those of the metachert by $4.0 \%$ and $8.0 \%$, respectively (Table 7 , Fig. 9). This trend may indicate that the externally derived fluids with lower $\delta^{18} \mathrm{O}$ values (magmatic fluid in equilibrium with the granitic rocks or local meteoric water) were responsible for the vein formation along with the metamorphic fluid that was generated by the devolatilization reactions and subsequently focused in veins. The restricted occurrence of molybdenite in the quartz veins appears consistent with this suggestion, i.e., Mo was supplied by externally derived hydrothermal fluids at the vein stage. However, an alternative interpretation is possible for the origin of Mo and other minor elements as well (see below).

\section{Mineralization of minor elements}

Several mineral assemblages that are useful in constraining the conditions of formation were recognized in the Nagasawa deposit, i.e., coexistence of chalcopyrite, pyrrhotite, and sphalerite ( 15.8 to $21.0 \mathrm{~mole} \% \mathrm{FeS}$; Table 6) and of chalcopyrite, pyrrhotite, and native bismuth, and the presence of löllingite. The conditions of temperature and sulfur fugacity, $f\left(\mathrm{~S}_{2}\right)$, estimated from the above mineral assemblages are given in Figure 10, along with the temperature range for the bedded ores and vein formation estimated from the oxygen isotopic fractionations. Thermodynamic data necessary to draw the figure were taken from Barton $(1973,1979)$. The chalcopyrite - pyrrhotite - sphalerite assemblage (Fig. 3c) formed at temperatures below $334^{\circ} \mathrm{C}$ and at $f\left(\mathrm{~S}_{2}\right)$ values close to the pyrite - pyrrhotite curve within analytical uncertainty (Barton 1979). The chalcopyrite - pyrrhotite - native bismuth assemblage (Fig. 3d), although uncommon, indicates lower temperatures (less than $\left.253^{\circ} \mathrm{C}\right)$ and $f\left(\mathrm{~S}_{2}\right)$ conditions than those of the chalcopyrite - pyrrhotite - sphalerite. The löllingite - native bismuth assemblage (Fig. 3e) is characteristic of even lower $f\left(\mathbf{S}_{2}\right)$ values, although the temperature is not well constrained. The former two assemblages indicate a temperature lower than those of the contact metamorphism $\left(\sim 440-570^{\circ} \mathrm{C}\right)$. The temperature thus decreased from that of contact metamorphism, including the vein formation, to the mineralization of the minor elements. This conclusion is also supported by the textural evidence that the minor minerals formed later than garnet and pyroxenoids (e.g., Fig. 3c). 
Distinct values of $f\left(\mathrm{~S}_{2}\right)$ and temperature estimated for each of the above assemblages reflect the local heterogeneity (at a microscopic scale) in temperature and $f\left(\mathrm{~S}_{2}\right)$. This view agrees with the inference based on oxygen isotopic data of the bedded ores, that oxygen isotopic equilibrium was not attained on a hand-specimen scale among any mineral pairs, and thus that the externally derived fluid media were not important. The $f\left(\mathrm{~S}_{2}\right)$ values and mineral assemblages were controlled locally by the source minerals or elements available at the site of crystallization. The source of the minor elements is inferred to be a chlorite- and pyrite-bearing assemblage, locally abundant in the precursor manganese carbonate ores, as discussed below.

The minor elements are now observed in the accessory minerals closely associated with garnet- 1 in the pyroxmangite - garnet - amphibole ore (Fig. 3c). This association strongly suggests that both $\mathrm{Al}$ in garnet-1 and the minor elements, along probably with $\mathrm{Mg}$ and $\mathrm{Fe}^{2+}$ in amphibole, were derived from the same source material, which we infer to be chlorite. The minor elements are considered to have been concentrated in a chlorite-bearing assemblage in the precursor manganese carbonate ores either as pyrite and other sedimentary minerals or organometallic compounds closely associated with chlorite, as impurity elements that substitute for octahedrally coordinated $\mathrm{Mg}$ and $\mathrm{Fe}^{2+}$ in the chlorite structure, or as a combination of those. Pyrite, the earliest sulfide phase in the Nagasawa deposit, may be sedimentary in origin, formed by sedimentation or diagenesis, and recrystallized during the early stage of contact metamorphism. Some of Ni and As may have been derived from pyrite, as suggested by the electronmicroprobe data (Table 4). Banno et al. (1999) described sulfide-bearing (pyrite, pyrrhotite, chalcopyrite, and sphalerite) graphitic metapelite from Nagasawa

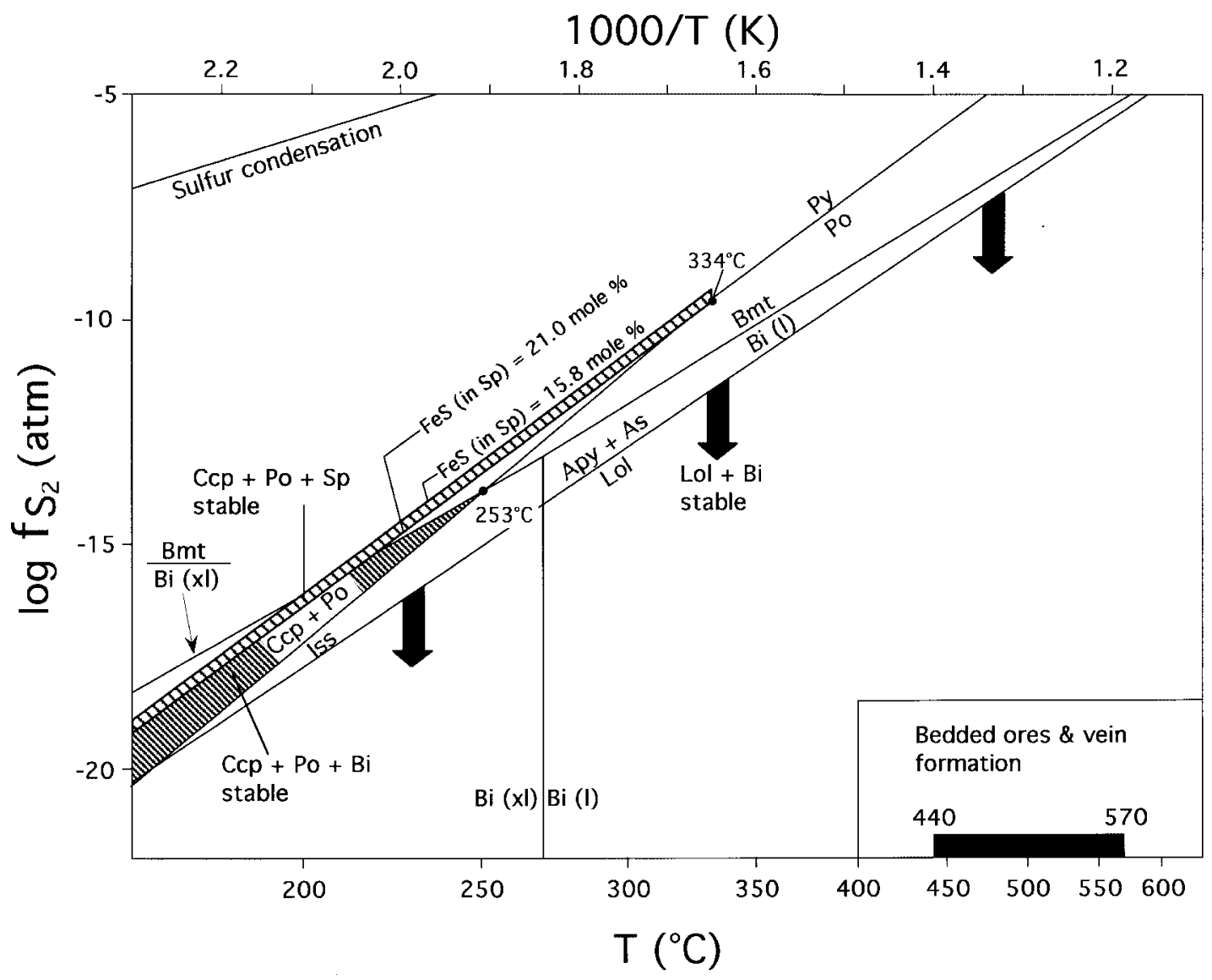

FIG. 10. $\log f\left(\mathrm{~S}_{2}\right)-\mathrm{T}$ relationship among sulfide minerals from the Nagasawa deposit. Note that the mineral assemblages chalcopyrite - pyrrhotite - sphalerite, chalcopyrite - pyrrhotite - native bismuth, and native bismuth - löllingite occupy distinct regions in the diagram. 
interbedded with the same metachert unit hosting the manganese deposit, and inferred the protolith of this metapelite to be black shale, rich in both metals and organic materials, interbedded with bedded chert. The presence of such a rock type is consistent with the suggestion that the minor elements were derived from the chlorite- and pyrite-bearing assemblage.

For the chert-hosted bedded manganese deposits in other areas, no analyses have been made of chlorite or pyrite fractions in the rhodochrosite-rich ores except several bulk-rock chemical compositions (e.g., Matsumoto 1987, Hein et al. 1987, Huebner \& Flohr 1990, Sugisaki et al. 1991). Sugisaki et al. (1991) analyzed (X-ray fluorescence) bulk-rock samples of the manganese carbonate ores, the "manganese bands", composed of rhodochrosite spherules of up to several $\mathrm{mm}$ in size in a siliceous or argillaceous matrix, from the Mino Belt. They recognized that trace metals such as $\mathrm{Co}, \mathrm{Ni}, \mathrm{Cu}, \mathrm{Zn}$, and $\mathrm{Mo}$ are highly concentrated in the rhodochrosite ores relative to their host rocks. They documented ranges of concentration from 19 to $344 \mathrm{ppm}$ $\mathrm{Co}$, from 36 to $64 \mathrm{ppm} \mathrm{Ni}$, from 44 to $298 \mathrm{ppm} \mathrm{Cu}$, from 59 to $113 \mathrm{ppm} \mathrm{Zn}$, up to $173 \mathrm{ppm} \mathrm{Mo,} \mathrm{and} \mathrm{from}$ 18 to $99 \mathrm{ppm} \mathrm{Pb}$ in the rhodochrosite ores. None of those trace metals were detected, however, in the rhodochrosite spherules by electron microprobe, even where the bulk trace-metal concentrations were found to be higher than the detection limit ( 100 ppm). Sugisaki et al. (1991) suggested from those observations that the minor metals may have been adsorbed as organic compounds onto the surfaces of matrix clays. Hein et al. (1987) also noted an enrichment of $\mathrm{Zn}$ and $\mathrm{Ni}$ in the stratiform rhodochrosite ores compared with the host chert and shale, although no enrichment was observed for $\mathrm{Co}$ and $\mathrm{Cu}$. The results of Matsumoto (1987) are not consistent with those of Sugisaki et al. (1991); no enrichment of the minor metals such as $\mathrm{Cu}, \mathrm{Ni}$, and $\mathrm{Zn}$ were recognized in the rhodochrosite-rich nodules compared with the host rocks (bedded chert or siliceous shale of the Middle Jurassic). The inconsistency in pattern of metal enrichment among the above studies remains poorly understood, as the mineralogy of the rhodochrosite ores, especially the proportion of rhodochrosite, clays, and pyrite, was not clearly specified.

Chlorite-group minerals containing minor ore-forming elements as octahedrally coordinated cations have been found in many previous studies (Bailey 1988, Deer et al. 1992). Any medium-sized cations such as $\mathrm{Cr}, \mathrm{Ni}$, $\mathrm{Mn}, \mathrm{V}, \mathrm{Cu}$, and $\mathrm{Zn}$, along with $\mathrm{Mg}, \mathrm{Fe}^{2+}, \mathrm{Fe}^{3+}$, and $\mathrm{Al}$, will be incorporated in the octahedral sites of the chlorite structure (Bailey 1988). Among those elements, Mn, $\mathrm{Ni}$, and $\mathrm{Zn}$ can be predominant cations in the octahedral sites of the chlorite structure, and such chlorites are recognized as independent minerals, i.e., pennantite, nimite, and baileychlore, respectively (De Waal 1970, Rule \& Radke 1988). More recently, Miyaike et al. (2000) found chlorite with high $\mathrm{Ni}$ and $\mathrm{Zn}$ contents from hydrothermally altered basalt developed in the footwall of the Ghuzayn volcanogenic massive sulfide deposit in Oman, and commented on the capacity of chlorite for accommodation of trace elements.

The sulfur in sulfides is considered to have been derived from the decomposition of pyrite. This mineral is commonly replaced by pyrrhotite with characteristic microfractures (Fig. 3f), which reflect the negative change in volume, or shrinkage, of solid phases during such replacement. This replacement reaction can be expressed as:

$$
\underset{\text { Py }}{7 \mathrm{FeS}_{2}+\underset{\text { monoclinic Po }}{6 \mathrm{H}_{2}} \rightarrow \mathrm{Fe}_{7} \mathrm{~S}_{8}+6 \mathrm{H}_{2} \mathrm{~S}}
$$

The volume change in solid phases involved in this reaction $\left(\Delta \mathrm{V}_{\text {solid }}\right)$ can be calculated as:

$$
\begin{aligned}
& \Delta \mathrm{V}_{\text {solid }}=\mathrm{V}_{\mathrm{Po}}-7 \mathrm{~V}_{\mathrm{Py}}=140.75\left(\mathrm{~cm}^{3} / \mathrm{mole}\right)- \\
& 7 \times 23.94\left(\mathrm{~cm}^{3} / \mathrm{mole}\right)=-26.83\left(\mathrm{~cm}^{3}\right)
\end{aligned}
$$

where $\mathrm{V}_{\mathrm{Po}}$ and $\mathrm{V}_{\mathrm{Py}}$ represent molar volumes of monoclinic pyrrhotite and pyrite, respectively (values from Murowchick 1992). This $\Delta \mathrm{V}_{\text {solid }}$ of $-26.83 \mathrm{~cm}^{3}$ is equivalent to a volume decrease of $16 \%$. This replacement reaction generated $\mathrm{H}_{2} \mathrm{~S}$ that subsequently reacted with other minor elements and $\mathrm{Fe}$ to form sulfides and sulfarsenides.

\section{Origin of the minor elements}

In order to characterize the minor elements in the Nagasawa deposit, concentration coefficients of elements in manganese nodules relative to both the Earth's crust and deep-sea sediments are shown in Figure 11. All the characteristic minor elements in the Nagasawa deposit, i.e., the elements that occur exclusively as major constituents in the sulfide and other minor minerals ( $\mathrm{S}, \mathrm{Co}, \mathrm{Ni}, \mathrm{Cu}, \mathrm{Zn}, \mathrm{Mo}, \mathrm{As}, \mathrm{Te}, \mathrm{Pb}$, and $\mathrm{Bi}$ ), are consistent with those that are more concentrated in manganese nodules over the average crust by one to three orders of magnitude. However, some elements have higher concentration coefficients than all the minor elements and $\mathrm{Mn}$, but they are not found as independent mineral phases in the Nagasawa deposit. These elements are I, Tl, Sb, W, Cd, B, Cl, and Pt. Among them, Sb and $\mathrm{Cd}$ occur as minor constituents in gersdorffite, nickeline, hedleyite, and parkerite (for Sb, see Tables 3 and 4) and in sphalerite (for Cd, see Table 5), respectively. Preliminary electron-microprobe analyses revealed that a small amount of chlorine is present in apatite. The concentration of platinum is expected to be still too low (on the order of several hundred ppb), if enriched, to crystallize as an independent mineral. Minerals containing B or W have been reported from several bedded manganese deposits in Japan, such as hübnerite, tinzenite, and wiserite (e.g., Watanabe et al. 1970), although no such minerals have been recognized in this study; the reasons for their absence remain unclear. Huebner \& Flohr 


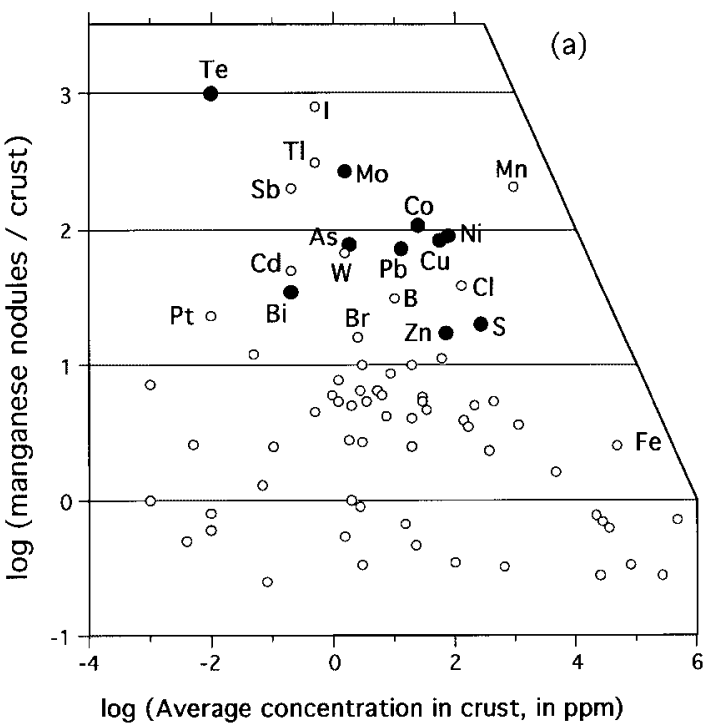

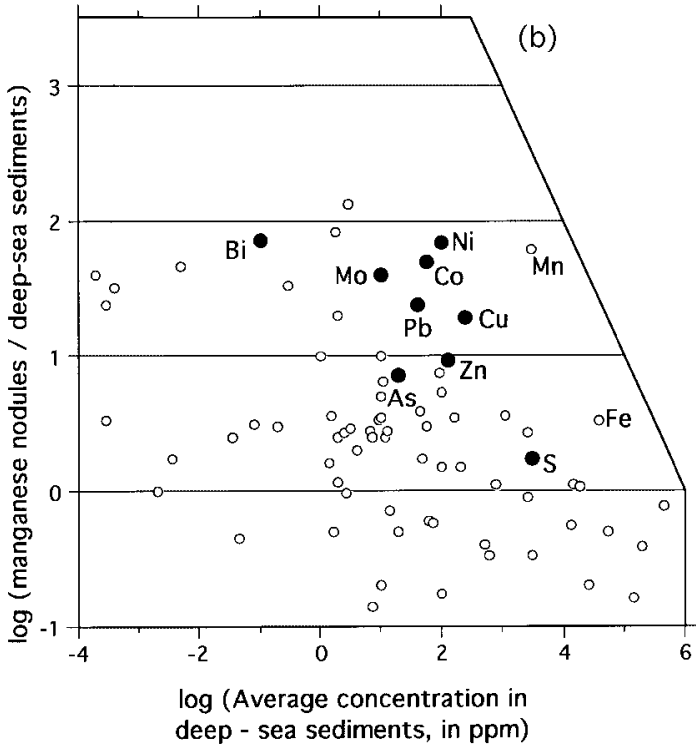

Elements in element, sulfide, and arsenide minerals in Nagasawa Other elements (for comparison)

FIG. 11. Concentration coefficients of elements in ferromanganese nodules relative to (a) the average crust and (b) deep-sea sediments versus average abundances in the crust and in the deep-sea sediments (in ppm). The concentration coefficient for each element is defined as log (average concentration in manganese nodules / average concentration in the crust or in deepsea sediments). Average concentrations of elements in manganese nodules and deep-sea sediments were taken from Baturin (1988), and those in the crust were taken from Mason \& Moore (1982), respectively. No data on the average concentration of Te in the deep-sea sediments were found in the literature.

(1990) showed a positive correlation between tungsten contents and modal proportion of gageite in the cherthosted manganese ores of the Franciscan Complex. The absence of tungsten in the Nagasawa ores may imply the absence of specific precursor minerals such as gageite. Iodine and thallium are, in general, extremely rare as major constituent elements in independent mineral phases.

The consistency of the elements enriched in the Nagasawa manganese deposit and in the seafloor manganese oxide-hydroxide phases suggests that the deposit could have originated from a precursor like ferromanganese nodules, crusts, or particulates of hydrogenous, diagenetic, or hydrothermal origin, and that the polymetallic nature of the deposit was probably inherited from the nature of the precursor.

Sediment-hosted stratiform manganese carbonate deposits, the most probable protoliths of the Nagasawa deposit, have interested many previous investigators (e.g., Hein \& Koski 1987, Hein et al. 1987, Matsumoto 1987, Okita et al. 1988, Okita \& Shanks 1992, Sugisaki et al. 1991), most of which suggested that those manga- nese carbonate ores formed under hemipelagic environments during suboxic diagenesis by the oxidation of organic matter (and in some cases methane) to carbonates and the reduction of manganese oxides-oxyhydroxides to $\mathrm{Mn}^{2+}$ to form rhodochrosite. In this context, the minor elements were first scavenged from seawater, pore water in deep-sea sediments, or seafloor hydrothermal fluids by the deep-sea manganese oxides-oxyhydroxides, as indicated by the relative enrichment of those elements in ferromanganese nodules over the average pelagic sediments (Fig. 11b), and were released and subsequently incorporated in chlorite during diagenetic reconstitution of the manganese oxide to the manganese carbonate ores, probably under hemipelagic environments (Fig. 12).

\section{Conclusions}

(1) The Nagasawa deposit is a chert-hosted bedded manganese deposit that was subjected to intense contact metamorphism. Sulfides and other minerals of the minor elements ( $\mathrm{Co}, \mathrm{Ni}, \mathrm{Cu}, \mathrm{Zn}, \mathrm{As}, \mathrm{Te}, \mathrm{Pb}$, and $\mathrm{Bi}$ ) 


\section{Evolution of the Ores}

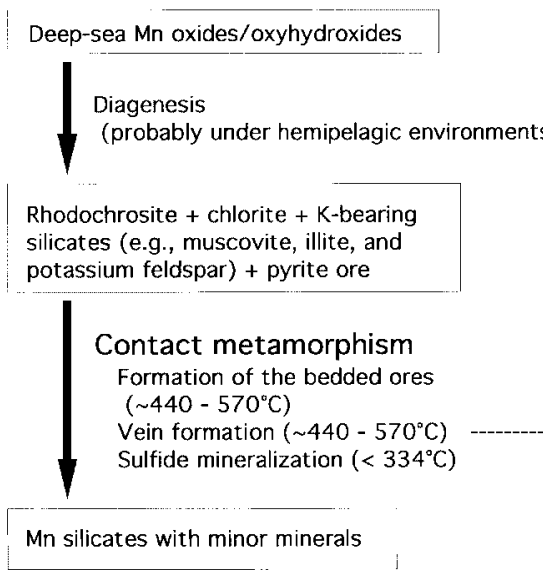

\section{Minor elements}

(S, Co, Ni, Cu, $\mathrm{Zn}, \mathrm{Mo}$, As, Te, Pb, Bi)

In Mn oxides/oxyhydroxides

In the chlorite- and pyrite-bearing assemblage

FIG. 12. Schematic representation of the evolution of ore assemblages and the behavior of minor elements in the Nagasawa deposit.

that are distributed widely in the deposit formed by recrystallization during contact metamorphism after the formation of silicates in both the bedded ores and the veins, rather than by precipitation from hydrothermal fluids driven by the emplacement of granitic magma during metamorphism.

(2) The minor elements were concentrated in chlorite- and pyrite-bearing assemblages in the unmetamorphosed rhodochrosite-quartz-dominant ores before contact metamorphism. Breakdown of this assemblage into the garnet-bearing assemblage released the minor elements that subsequently reacted with $\mathrm{H}_{2} \mathrm{~S}$, generated by the replacement reaction of pyrite by pyrrhotite, to form sulfide minerals.

(3) Concentration of the minor elements was probably achieved in deep-sea environments by scavenging and accumulation in manganese oxides such as ferromanganese nodules of hydrogenous, diagenetic, or hydrothermal origin. Those minor elements were incorporated in chlorite- and pyrite-bearing assemblages during the diagenetic reconstitution of manganese oxides to the rhodochrosite-quartz-dominant ores, probably under hemipelagic environments.

\section{ACKNOWLEDGEMENTS}

We express our gratitude to Dr. F. Mancini for valuable discussions on the manganese deposits and instructions in the measurement of $2 \mathrm{~V}$ of pyroxmangite and rhodonite. We also thank Drs. R. Gieré, P. Marescotti, and R.F. Martin, whose suggestions and comments have greatly improved the manuscript.

\section{REFERENCES}

ARAKAWA, Y. \& TAKAHASHI, Y. (1988): Rb-Sr ages of granitic rocks from the Tsukuba district, Japan. J. Mineral. Petrogr. Econ. Geol. 83, 232-240.

Bailey, S.W. (1988): Chlorites: structures and crystal chemistry. In Hydrous Phyllosilicates (Exclusive of Micas) (S.W. Bailey, ed.). Rev. Mineral. 19, 347-403.

Banno, Y., Bunno, M., Haruna, M. \& Kono, M. (1999): Vivianite from Nagasawa, Iwama-machi, Ibaraki Prefecture, Japan - new finding from meta-pelitic rocks. Geol. Surv. Japan, Bull. 50, 117-121 (in Japanese with English abstr.).

BARTON, P.B., JR. (1973): Solid solutions in the system $\mathrm{Cu}-$ $\mathrm{Fe}-\mathrm{S}$. I. The $\mathrm{Cu}-\mathrm{S}$ and $\mathrm{CuFe}-\mathrm{S}$ joins. Econ. Geol. 68, 455465.

(1979): Sulfide mineral stabilities. In Geochemistry of Hydrothermal Ore Deposits (2nd edition, H.L. Barnes, ed.). John Wiley \& Sons, New York, N.Y. (278-403).

BAsso, R., Lucchetti, G. \& ZefiRo, L. (1992): Reppiaite, $\mathrm{Mn}_{5}(\mathrm{OH})_{4}\left(\mathrm{VO}_{4}\right)_{2}$, a new mineral from Val Graveglia (northern Appennines, Italy). Z. Kristallogr. 201, 223-234.

BAtURIN, G.N. (1988): The Geochemistry of Manganese and Manganese Nodules in the Ocean. D. Reidel Publishing Company, Dordrecht, The Netherlands.

BRUGGER, J. \& GIERÉ, R. (2000): Origin and distribution of some trace elements in metamorphosed Fe-Mn deposits, Val Ferrera, eastern Swiss Alps. Can. Mineral. 38, 1075-1101. 
Cabella, R., Lucchetti, G. \& Marescotti, P. (2001): Authigenic monazite and xenotime from pelitic metacherts in pumpellyite-actinolite-facies conditions, SestriVoltaggio zone, central Liguria, Italy. Can. Mineral. 39, 717-727.

Cortesogno, L. \& Lucchetti, G. (1984): Ocean-floor metamorphism of the volcanic and sedimentary sequences in the northern Appennine ophiolites: mineralogical and paragenetic features. Ofioliti 9, 363-400.

Craig, J.R. \& ScotT, S.D. (1974): Sulfide phase equilibria. In Sulfide Mineralogy (P.H. Ribbe, ed.). Rev. Mineral. 1, CS1-110.

Deer, W.A., Howie, R.A. \& Zussman, J. (1992): An Introduction to the Rock-Forming Minerals (2nd ed.). Longman Group, U.K.

DE WAAL, S.A. (1970): Nickel minerals from Barberton, South Africa. II. Nimite, a nickel-rich chlorite. Am. Mineral. 55, 18-30.

Haruna, M. (2001): Nagasawa deposit. In An Illustrated Guide to the Japanese Ore Deposits (M. Aoki, ed., CD-ROM). Soc. Resource Geol., Tokyo, Japan (in Japanese).

\& Онмото, H. (1996): Oxygen and carbon isotope studies on the skarn-type ores at the Tengumori copper deposit of the Kamaishi mine, northeastern Japan. Resource Geol. 46, 125-136.

Ueno, H. \& Онмото, H. (1990): Development of skarn-type ores at the Tengumori copper deposit of the Kamaishi mine, Iwate Prefecture, northeastern Japan. Mining Geol. 40, 223-244.

Hayashi, K. \& Oнмото, H. (1996): Oxygen isotope study of metamorphosed manganese deposits of the NodaTamagawa mine, northeast Japan. J. Mineral. Petrogr. Econ. Geol. 91, 408-418.

Hein, J.R. \& Koski, R.A. (1987): Bacterially mediated diagenetic origin for chert-hosted manganese deposits in the Franciscan Complex, California Coast Ranges. Geology 15, $722-726$

\& Yeh, Hsueh-Wen (1987): Cherthosted manganese deposits in sedimentary sequences of the Franciscan complex, Diablo Range, California. In Siliceous Sedimentary Rock-Hosted Ores and Petroleum (J.R. Hein, ed.). Van Nostrand and Reinhold, New York, N.Y. (206230),

HoRI, N. \& SASHIDA, K. (1998): Mesozoic strata of the Keisoku Mountain Block in the Yamizo Mountains, central Japan. J. Geography 107, 493-511 (in Japanese, English abstr.).

Huebner, J.S. \& Flohr, M.J.K. (1990): Microbanded manganese formations: protoliths in the Franciscan Complex, California. U.S. Geol. Surv., Prof. Pap. 1502.

Kawano, Y. \& UedA, Y. (1966): K-Ar dating on the igneous rock in Japan. IV. Granitic rocks of Backbone Range in northeastern Japan and its western district. Sci. Rep. Tohoku Univ., Ser. III, 9, 525-539.

Leake, B.E., Woolley, A.R., ArPs, C.E.S., Birch, W.D., Gilbert, M.C., Grice, J.D., Hawthorne, F.C., Kato, A., Kisch, H. J., KRivovichev, V.G., Linthout, K., LAIRD, J., Mandarino, J., Maresch, W.V., Nickel, E.H., Rock, N.M.S., Schumacher, J.C., Smith, D.C., Stephenson, N.C.N., Ungaretti, L., WhitTAKer, E.J.W. \& YouZhi, G. (1997): Nomenclature of amphiboles: report of the Subcommittee on Amphiboles of the International Mineralogical Association Commission on New Minerals and Mineral Names. Can. Mineral. 35, 219-246.

Lichtenstein, U. \& Hoernes, S. (1992): Oxygen isotope fractionation between grossular-spessartine garnet and water: an experimental investigation. Eur. J. Mineral. 4, 239-249.

Mancini, F., Alviola, R., Marshall, B., Satoh, H. \& PAPUnEN, H. (2000): The manganese silicate rocks of the early Proterozoic Vittinki Group, southwestern Finland: metamorphic grade and genetic interpretations. Can. Mineral. 38, 1103-1124.

Marchesini, M. \& Pagano, R. (2001): The Val Graveglia manganese district, Liguria, Italy. Mineral. Rec. 32, 349379,415 .

Marescotti, P. \& Frezzotti, M.L. (2000): Alteration of braunite ores from eastern Liguria (Italy) during syntectonic veining processes: mineralogy and fluid inclusions. Eur. J. Mineral. 12, 341-356.

Mason, B. \& Moore, C.B. (1982): Principles of Geochemistry ( $4^{\text {th }}$ ed.). John Wiley and Sons, New York, N.Y.

Matsumoto, R. (1987): Origin of manganese nodules in the Jurassic siliceous rocks of the Inuyama district, central Japan. In Siliceous Sedimentary Rock-Hosted Ores and Petroleum (J.R. Hein, ed.). Van Nostrand and Reinhold, New York, N.Y. (181-205)

MITI (Ministry of International Trades and Industry) (1987): Annual Report on the exploration of rare metals (Kasama area). (in Japanese)

Miyaike, S., Mizuta, T., Ishiyama, D. \& Nakashima, K. (2000): Geochemical characteristics of trace element distribution in ores and host rocks in the Ghuzayn $\mathrm{Cu}$ VMS deposit, Oman. 50th Ann. Meeting, Soc. Resource Geol. (Tokyo), Abstr. O-24 (in Japanese).

MiYazaki, K., Sasada, M. \& Hattori, H. (1992): Low P/T metamorphic rocks formed at different pressure levels around the Tsukuba Mountains, Japan. J. Geol. Soc. Japan 98, 713-722 (in Japanese, English abstr.).

\& Yoshioka, T. (1996): Geology of the Makabe district (with Geological Map at 1:50,000). Geol. Surv. Japan (in Japanese, English abstr.).

Momoi, H., Kudo, Y. \& MinaKawa, T. (1988): Syntheses of spherulitic rhodochrosites in gels and the natural occur- 
rence. J. Mineral. Soc. Japan 18, 235-246 (in Japanese, English abstr.).

MurowChICK, J.B. (1992): Marcasite inversion and the petrographic determination of pyrite ancestry. Econ. Geol. 87, 1141-1152.

Okita, P.M., Maynard, J.B., Spiker, E.C. \& Force, E.R. (1988): Isotopic evidence for organic matter oxidation by manganese reduction in the formation of stratiform manganese carbonate ore. Geochim. Cosmochim. Acta 52, 2679-2685.

\& Shanks, W.C., III (1992): Origin of stratiform sediment-hosted manganese carbonate ore deposits: examples from Molango, Mexico, and TaoJiang, China. Chem. Geol. 99, 139-164.

Rule, A.C. \& RadKe, F. (1988): Baileychlore, the Zn end member of the trioctahedral chlorite series. Am. Mineral. 73, 135-139.

Sato, H., Yamaguchi, Y. \& Makino, K. (1997): Cl incorporation into successively zoned amphiboles from the Ramnes cauldron, Norway. Am. Mineral. 82, 316-324.

SATOH, H. (2000): Oxygen isotope microanalysis of a large orthopyroxene clast in A-881526 diogenite. Antarct. Meteor. Res. 13, 238-255.

SHARP, Z.D. (1990): A laser-based microanalytical method for the in situ determination of oxygen isotope ratios of silicates and oxides. Geochim. Cosmochim. Acta 54, 1353-1357.
ShEPPARD, S.M.F. (1986): Characterization and isotopic variations in natural waters. In Stable Isotopes in High Temperature Geological Processes (J.W. Valley, H.P. Taylor, Jr. \& J.R. O’Neil, eds.). Rev. Mineral. 16, 491-559.

ShibA, M., UedA, Y. \& ONUKi, H. (1979): K-Ar ages of metamorphic rocks from the Tsukuba district, Ibaraki Prefecture. J. Mineral. Petrogr. Econ. Geol. 74, 122-125.

Sugisaki, R., Sugitani, K. \& AdAchi, M. (1991): Manganese carbonate bands as an indicator of hemipelagic sedimentary environments. J. Geol. 99, 23-40.

TAYLOR, H.P., JR. (1974): The application of oxygen and hydrogen isotope studies to problems of hydrothermal alteration and ore deposition. Econ. Geol. 69, 843-883.

Watanabe, T., Yui, S. \& Kato, A. (1970): Bedded manganese deposits in Japan, a review. In Volcanism and Ore Genesis (T. Tatsumi, ed.). Univ. Tokyo Press, Tokyo, Japan (119142).

ZHeng, Yong-FeI (1993a): Calculation of oxygen isotope fractionation in anhydrous silicate minerals. Geochim. Cosmochim. Acta 57, 1079-1091.

(1993b): Calculation of oxygen isotope fractionation in hydroxyl-bearing silicates. Earth Planet. Sci. Lett. 120, 247-263.

Received December 22, 2001, revised manuscript accepted June 15, 2002. 